\title{
THE
}

\section{The geochemical cycling of reactive chlorine through the marine troposphere}

\author{
William C. Keene \\ Alexander A. P. Pszenny \\ Daniel J. Jacob \\ Robert A. Duce \\ University of Rhode Island \\ James N. Galloway
}

See next page for additional authors

Follow this and additional works at: https://digitalcommons.uri.edu/gsofacpubs

Terms of Use

All rights reserved under copyright.

\section{Citation/Publisher Attribution}

Keene, W. C., A. A. P. Pszenny, D. J. Jacob, R. A. Duce, J. N. Galloway, J. J. Schultz-Tokos, H. Sievering, and J. F. Boatman (1990), The geochemical cycling of reactive chlorine through the marine troposphere, Global Biogeochem. Cycles, 4(4), 407-430, doi: 10.1029/GB004i004p00407.

Available at: http://dx.doi.org/10.1029/GB004i004p00407

This Article is brought to you for free and open access by the Graduate School of Oceanography at DigitalCommons@URI. It has been accepted for inclusion in Graduate School of Oceanography Faculty Publications by an authorized administrator of DigitalCommons@URI. For more information, please contact digitalcommons-group@uri.edu. 


\section{Authors}

William C. Keene, Alexander A. P. Pszenny, Daniel J. Jacob, Robert A. Duce, James N. Galloway, Joseph J. Schultz-Tokos, Herman Sievering, and Joe F. Boatman 
Wi11 iam C. Keene, 1

Alexander A. P. Pszenny, 2 Daniel J. Jacob, 3

Robert A. Duce, 4 James $\mathrm{N}_{4}$ Ga1 loway, 1

Joseph J. Schultz-Tokos, 4,5

Herman Sievering, 6,7 and Joe F. Boatman 6

Abstract. Heterogeneous reactions involving sea-salt aerosol in the marine troposphere are the major global source for volatile inorganic chlorine. Wo measured reactant and product species hypothesized to be associated with these chemical transformations as a function of phase, particle size, and altitude over the North Atlantic Ocean during the summer of 1988. Concentrations of HCl were typically less than 1.0 ppbv near the sea surface and

\footnotetext{
${ }^{1}$ Department of Environmental Sciences, Unjuersity of Virginia, Charlottesville.

${ }^{2}$ Ocean Chemistry Division, NOAA Atlantic Oceanographic and Meteorological Laboratoryy, Miami, Florida.

${ }_{\text {Division of App1ied Sciences and }}$ Department of Earth and P1anetary Sciences, Harvard University, Cambridge, Massachusetts.

${ }^{4}$ Graduate School of Oceanography, University of Rhode Island, Narragansett.

$5_{\text {Now at Institut fuer Meereskunde an der }}$ Universitaet Kie1, Kie1, Germany.

6 Aeroso1 Research Section, NOAA Air Resources Laboratory, Boulder, Colorado.

7 Also at Center for Environmental Sciences, University of Colorado at Denver.

Copyright 1990

by the American Geophysical Union.
}

Paper number 90GB02425.

0886-6236/90/90GB-02425\$10.00 decreased with a1titude and with distance from the U.S. east coast. Concentrations of C1 volatilized from aerosols were generally equivalent to the corresponding concentrations of $\mathrm{HC} 1$ and ranged from less than detection 1 imits to 125 nmol $\mathrm{m}^{-3}$ STP. Highest absolute and percentage losses of particulate $C 1$ were typically associated with elevated concentrations of anthropogenic combustion products. Concentrations of product nss $\mathrm{SO}_{4}{ }^{2-}$ and $\mathrm{NO}_{3}{ }^{-}$in coarse aerosol fractions indicate that on average on1y $38 \%$ of measured $\mathrm{C1}^{-}$deficits could be acconted for by the combined effects of acid-base desorption and reactions invo1ving nonacidic $N$ gases. We hypothesize a mechanism for the C1 loss initiated by reaction of $\mathrm{O}_{3}$ at sea-salt aerosol surfaces, generating $\mathrm{Cl}_{2}$, followed by rapid photochemical conversion of $\mathrm{Cl}_{2}$ to $\mathrm{HC} 1$ via C1 atoms ( $\left.1^{\circ}\right)$ and eventual recapture of HC1 by the aerosol. Simulations with a zero-dimension (0-D) photochemical mode1 suggest that oxidation by $\mathrm{Cl}^{\circ}$ may be an important tropospheric sink for dimethyl sulfide and hydrocarbons. Under low-NO conditions, the rapid cycling of reactive C1 would provide a catalytic loss mechanism for $\mathrm{O}_{3}$, which would possibly explain the 1 ow $\mathrm{O}_{3}$ concentrations often observed above the world's oceans.

\section{INTRODUCTION}

The injection of sea-salt aerosol generated by breaking waves on the ocean's 
surface is the major global source for atmospheric C1 [Erickson and Duce, 1988]. Most of this $\mathrm{C}_{1}$ remains in the aerosol and is returned to the ocean surface $v i a$ dry and wet deposition, but important fractions, ranging from 3 to $20 \%$ on average, are released from the aerosol as inorganic C1 vapor ( $\mathrm{Cl}_{\mathrm{g}}$ ) [e.g., Cicerone, 1981]. Although this particle-to-gas conversion is by far the major source for gaseons C1 in the global troposphere [e.g., Friend, 1989], decades of research have failed to demonstrate conclusively the primary mechanism(s) involved. This is due in part to the fact that few studies have measured principal reactant and product species simultaneously as a function of phase and particle size in marine regions remote from continental influences.

HC1 is generally recognized as the major fraction of $\mathrm{Cl}^{\dot{\mathrm{i}}}$ in the marine troposphere [Ryan and ${ }^{8}$ Mukherjee, 1974; Wof sy and McElroy, 1974]. Thermodynamic considerations coupled with field measurements of aerosol chemistry and $\mathrm{Cl}^{\mathrm{i}}{ }^{\text {sug- }}$ gest that most of the HC1 may originate with direct volatilization from sea-salt aerosol which is acidified to $10 \mathrm{ow}$ pH $(<3)$ by the incorporation of $\mathrm{HNO}_{3}$ and $\mathrm{H}_{2} \mathrm{SO}_{4}$ (Eriksson, [1959], Duce, [1969], Martens et a1. [1973], Berg and Vinchester [1977], Kritz and Rancher [1980], Brimblecombe and Clegg [1988], Legrand and Delmas [1988], Wa11 et a1. [1988], among many others) as follow :

$\mathrm{HNO}_{3}(g)+\mathrm{NaCl}_{(p)}->\mathrm{HCl}_{(\mathrm{g})}+\mathrm{NaNO}_{3}(\mathrm{p})$

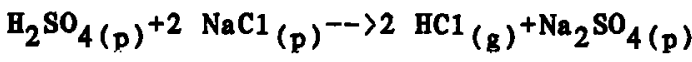

Although exchange between particulatephase $\mathrm{CI}^{-}$and $\mathrm{CI}^{i}$ has been demonstrated clearly by extensive field measurements, the importance of the acid-base desorption mechanism as the principal driver for $C 1$ phase change in the marine troposphere remains open to question [e.g., Cicerone, 1981; Friend, 1989].

A1ternative mechanisms involving reactions of various $\mathrm{N}$ gases with sea-salt aerosol have also been suggested as sources for chemically active halogen gases in the marine troposphere. Reaction of $\mathrm{NO}_{2}$ with sea-salt aerosol has been hypothesized [A1tshuller, 1958] and demonstrated to be a source for $\mathrm{Cl}^{\mathrm{i}}$ [Schroeder and Urone, 1974; Finlayson-Pitts, 1983] as follows:

$2 \mathrm{NO}_{2}(g)+\mathrm{NaCl}_{(p)} \rightarrow \mathrm{NOCl}_{(g)}+\mathrm{NaNO}_{3}(\mathrm{p})$
NOC1 has short 1 ifetimes against photo1ysis (5-30 min) and hydrolysis (0.03 s to $45 \mathrm{~min}$ ). Photolysis of NOC1 generates C1 atoms (C1') which may then initiate oxidation of hydrocarbons to produce HC1. Hydrolysis of NOC1 generates HONO(g), a source of $\mathrm{OH}$ radica $1(\mathrm{OH} \cdot)$, and HCl.' In both cases, the final products of these rapid reaction sequences are $\mathrm{HCl}$ and $\mathrm{NaNO}_{3}$, the same products expected from an acid-base desorption involving $\mathrm{HNO}_{3}$ (reaction (1)). Finlayson-Pitts et al. [1989] recentiy reported that $\mathrm{C}_{1} \mathrm{NO}_{3}$ and $\mathrm{N}_{2} \mathrm{O}_{5}$ react with $\mathrm{NaCl}$ aerosol to generate reactive $\mathrm{Cl}_{\mathrm{i}}^{\mathrm{i}}$ as follows:

$$
\mathrm{C1NO}_{3}(\mathrm{~g})+\mathrm{NaCl}_{(p)} \rightarrow \mathrm{Cl}_{2}(\mathrm{~g})+\mathrm{NaNO}_{3}(\mathrm{p})
$$

$\mathrm{N}_{2} \mathrm{O}_{5}(\mathrm{~g})+\mathrm{NaCl}_{(\mathrm{p})} \rightarrow \mathrm{ClNO}_{2}(\mathrm{~g})+\mathrm{NaNO}_{3}(\mathrm{p})$

Rapid photolysis of product $\mathrm{Cl}_{2}$ and $\mathrm{C}_{2} \mathrm{NO}_{2}$ generates $C 1^{\circ}$ and 1 timately HC1 through subsequent reactions. Again, the final products are $\mathrm{HC} 1$ and $\mathrm{NaNO}_{3}$. Considerable uncertainties exist in assessing the potential for a significant influence of reactions (3), (4), and (5) in the remote marine troposphere, but given the expected and observed concentrations of reactant $N$ gases [e.g., Levy and Moxim, 1989], it has been suggested that such transformations will be an important source for $\mathrm{Cl}^{\mathrm{i}}$ only in more polluted regions [e.g., Singh and Kasting, 1988].

The nature of heterogeneons reactions which generate $\mathrm{Cl}_{\mathrm{i}}$ have inportant implications for marine ${ }^{8}$ tropospheric chemistry. For instance, transformations involving $\mathrm{NO}_{2}, \mathrm{ClNO}_{3}$, and $\mathrm{N}_{2} \mathrm{O}_{5}$ generate highly reactive $C_{1}$ compounds which can initiate photochemical reactions in an analogous manner to ${ }^{\circ} \mathrm{OH}$, whereas acid-base desorption generates relatively unreactive HCl. The modeling investigation of $S$ ingh and Kasting [1988] suggests, however, that if ppbv concentrations of HC1 are generated by any mechanisms, reaction with $O H$ can produce sufficient $\mathrm{C} 1^{-}$to photooxidize a significant fraction (20 to $40 \%$ ) of nonmethane alkanes in the marine troposphere. It is clearly essential that the compounds involved, mechanisms of emission, and rates of reaction be identified nnequivocally if we are to understand major processes in the chemical cycling of $S, N, C$, odd 0 , odd $H$, and $C 1$ through this dynamic system.

The present study was designed to measure major reactant and product species 
which are thought to be involved in the heterogeneous generation of $\mathrm{Cl}^{\mathrm{j}}$. from reactions involving sea-salt aerosol in the marine troposphere. Hypothesized sources are assessed in 1 ight of these data.

\section{METHODS}

Ba1k- and size-segregated samples of atmospheric aerosol, some with simnltaneous samples of alkaline reactive $C 1, N$, and $S$ gases (hereinafter referred to as $\mathrm{HC1}$, $\mathrm{HNO}_{3}$, and $\mathrm{SO}_{2}$, respectively), were collected from an aircraft and a ship over the North Atlantic Ocean (NAO) during the summer of 1988 as part of the Global Change Expedition, Coordinated Air-Sea Experiment, and Western Atlantic Ocean Experiment (GCE/CASE/WATOX) [Pszenny et a1., 1990a]. Major features of sampling systems which generated data evaluated in this study are summarized in Table 1 . The University of Virginia (UVA) and the Air Quality Group (AQG; now referred to as the Aeroso1 Research Section) from the Nationa1 Oceanic and Atmospheric Administration (NOAA) sampled the western NAO boundary layer (BL) and free troposphere (FT) with a high-flow dichotomous filter pack system mounted on the NOAA Xing Air research aircraft [Bardwell et al., 1990]. Air was sampled within $250 \mathrm{~km}$ of the U.S. mid-Atlantic coast and in the vicinity of Be rmuda.

Atmospheric samples were al so collected with a variety of systems throughout the NAO from a 10-m bow tower on the NOAA ship Mt. Mitche11. UVA/AQG sampled major particulate- and vapor-phase species with a bulk filter pack system similar in design and operation to the bulk filter pack component of the dichotomous system deployed on the aircraft [Bardwe11 et a1., 1990]. Intercomparison with data from other measurement systems on the ship indicates that the open-face inlet on this shipboard sampler selectively excluded larger particles resulting in an approximate $20 \%$ nnderestimate of sea-salt species.

NOAA's At1antic Oceanographic and Meteorological Laboratory (AOML) sampled BL air from the ship with a filter pack system, a high-volume aerosol sampler (hivo1), and a six-stage cascade impactor [Pszenny et al.. 1990b]. In addition, the University of Rhode Island (URI) sampled atmospheric aerosol with seven-stage cascade impactor [Pszenny et al., 1989]. The AOML filter pack was designed to sam- ple fine aerosol and alkaline reactive $N$ and $S$ gases preferentially. Intercomparison with other data sets for shipboard collections suggests that the inlet for this sampler selectively excluded approximate1y two thirds of the sea-salt aerosol mass. Re1ationships between wind velocity and sea-salt aerosol concentrations measured with the AOM hivol were similar to those observed some years ago in the NAO with an isokinetic sampler [Lovett, 1978] suggesting that the hivol collected representative samples of sea-salt aerosol mass.

A number of potential artifacts could bias data for size-segregated aerosol generated with cascade impactors in marine regions. These include internal losses on slot throats of $25 \%$ to $30 \%$ [Willeke, 1975], significant retention of $\mathrm{HC} 1$ by Whatman 41 substrates for contact times longer that about 1 ms [Fogg, 1986], and inefficient retention of submicron aerosol by Whatman 41 backup filters [Lodge, 1986]. Although internal losses may have introduced modest negative bias for impactor data reported in this paper, other artifacts were probably not important. Calculated contact times for the cascade samplers were typical1y less than $1 \mathrm{~ms}$, suggesting that retention of $\mathrm{HCl}$, and by analogy $\mathrm{INO}_{3}$, was probably minimal under our sampling conditions. In addition, a large body of information indicates that Whatman 41 filters collect representativo samples of submicron aerosol [e.g., Lowentha1 and Rahn, 1987; Watts et a1., 1987: Kitto and Anderson, 1988].

The qualities of most data sets evaluated in this study have been assessed by thorough in-house testing and by intercomparison [e.g., Bardwe11 et a1.. 1990; Boatman et a1., 1990; Pszenny et a1.. 1990b]. There were, however, no independent measurements of HC1 by other groups to intercompare with measurements by UVA and AQG. Given this lack of independent information, and in 1 ight of the importance of these data for the present study, we include in the appendix a brief assessment for the quality of HC1 and non-seasalt (nss) $\mathrm{C}^{-}$data generated during the experiment. Results indicate that particle-to-particle and gas-to-particle reactions on bulk aerosol prefilters may cause large (factor of 2) positive bias in measurement of $\mathrm{HCl}$ and negative bias in measurement of particulate nss $\mathrm{C1}^{-}$. As such, we recommend that published data for these species which were generated using bulk prefilters be viewed with caution. 
TABLE 1. Samp1 ing

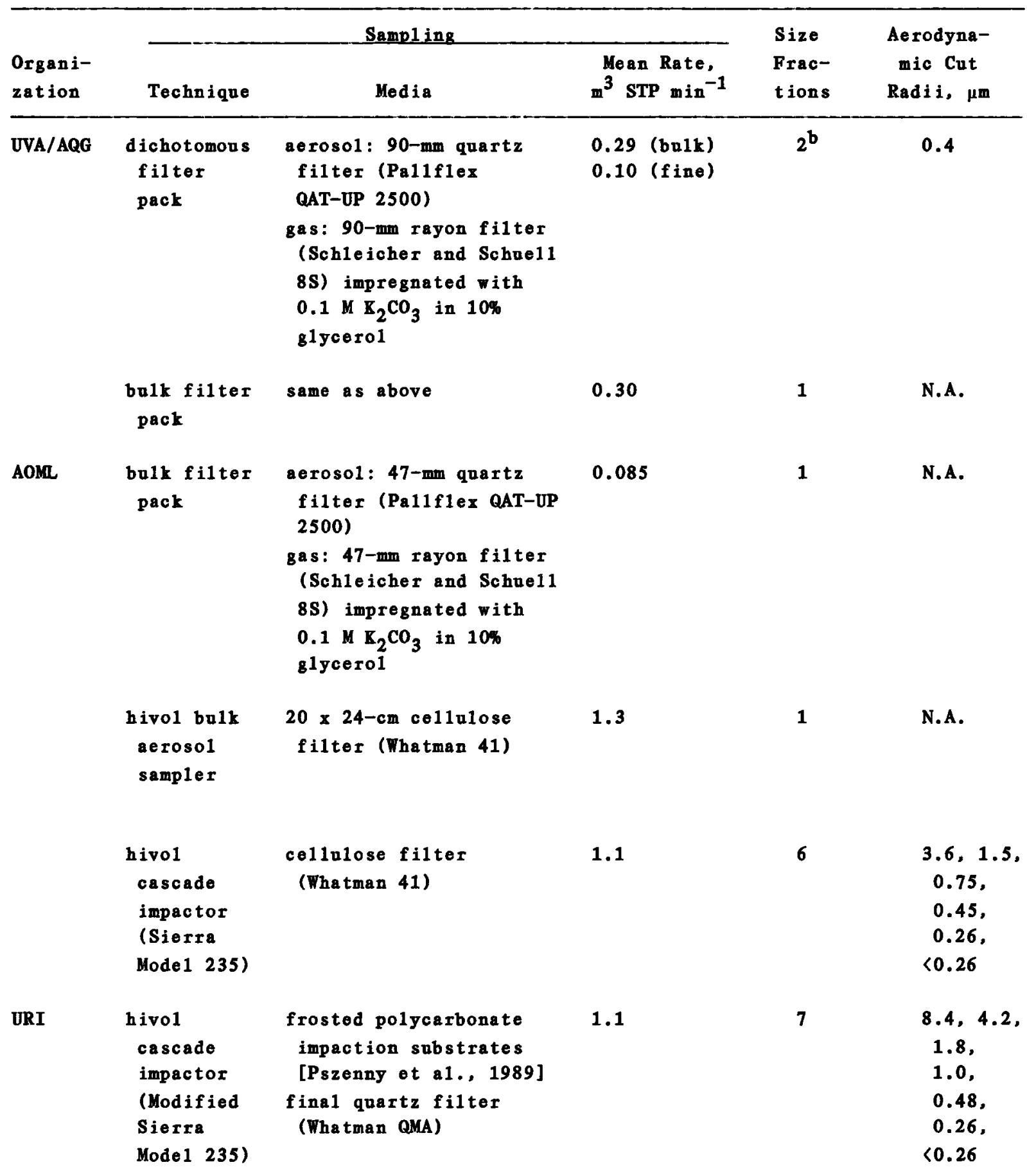

Abbreviations are as follows: UVA, University of Virginia; AQG, NOAA Air Quality Group; AOML, NOAA Atlantic Oceanographic and Meteorological Laboratory; URI, University of Rhode Island; FT, free troposphere; BL, boundary layer; N.A., not applicable. 
Systems

\begin{tabular}{|c|c|c|c|c|c|}
\hline $\begin{array}{l}\text { Species Me } \\
\text { Aerosols }\end{array}$ & Gred & $\begin{array}{l}\text { Average } \\
\text { Deployment } \\
\text { Time, hours }\end{array}$ & Platform & $\begin{array}{c}\text { Cruise } \\
\text { Leg }\end{array}$ & $\begin{array}{l}\text { Number } \\
\text { of } \\
\text { Samples }\end{array}$ \\
\hline $\begin{array}{l}\mathrm{SO}_{4}^{2-}, \mathrm{NO}_{3}^{-}, \\
\mathrm{Cl}^{-}, \\
\mathrm{CH}_{3} \mathrm{SO}_{3}^{-}, \\
\mathrm{HCOO}_{\mathrm{t}}, \\
\mathrm{CH}_{3} \mathrm{COO}_{\mathrm{t}^{\prime}}, \\
\mathrm{NH}^{+}, \\
\mathrm{Na}^{+}, \mathrm{Mg}^{2+}, \\
\mathrm{K}^{+}, \mathrm{Ca}^{2+}\end{array}$ & $\underset{\mathrm{HC} 1}{\mathrm{SO}_{2}, \mathrm{HNO}_{3},}$ & $\begin{array}{l}1.5(\mathrm{FT})^{b} \\
0.8(\mathrm{BL})^{b}\end{array}$ & aircraft & 1 & $\begin{array}{r}8(\mathrm{FT}) \\
16(\mathrm{BL})\end{array}$ \\
\hline $\begin{array}{l}\text { same as } \\
\text { above }\end{array}$ & $\begin{array}{l}\text { same as } \\
\text { above }\end{array}$ & 1.0 & ship & 1 & 20 \\
\hline $\begin{array}{l}\mathrm{SO}_{4}^{2-}, \mathrm{NO}_{3}^{-}, \\
\mathrm{Cl}^{-}, \\
\mathrm{CH}_{3} \mathrm{SO}_{3}^{-}, \\
\mathrm{NH}_{+}^{+}, \\
\mathrm{Na}^{+}, \mathrm{Mg}^{2+}, \\
\mathrm{K}^{+}, \mathrm{Ca}^{2+}\end{array}$ & $\mathrm{SO}_{2}, \mathrm{HNO}_{3}$ & 11.4 & ship & $\begin{array}{l}1 \\
2 \\
3 \\
4\end{array}$ & $\begin{array}{l}22 \\
15 \\
11 \\
21\end{array}$ \\
\hline $\begin{array}{l}\text { same as } \\
\text { above }\end{array}$ & N.A. & 26.3 & ship & $\begin{array}{l}1 \\
2 \\
3 \\
4\end{array}$ & $\begin{array}{r}10 \\
5 \\
3 \\
6\end{array}$ \\
\hline $\begin{array}{c}\text { same as } \\
\text { above }\end{array}$ & N.A. & 32.7 & $\operatorname{ship}$ & $\begin{array}{l}1 \\
3 \\
4\end{array}$ & $\begin{array}{l}1 \\
3 \\
2\end{array}$ \\
\hline $\begin{array}{l}\text { same as } \\
\text { above }\end{array}$ & N.A. & 71.5 & ship & $\begin{array}{l}3 \\
4\end{array}$ & \\
\hline
\end{tabular}

${ }^{\mathrm{a}} \mathrm{SO}_{4}{ }^{2-}, \mathrm{NO}_{3}{ }^{-}, \mathrm{Cl}^{-}, \mathrm{CH}_{3} \mathrm{SO}_{3}^{-}, \mathrm{HCOO}_{\mathrm{t}}, \mathrm{CH}_{3} \mathrm{COO}_{\mathrm{t}}, \mathrm{SO}_{2}$, and $\mathrm{HNO}_{3}$ were analyzed by ion chromatography. $\mathrm{NH}_{4}^{+}$was analyzed by automated colorimetry. $\mathrm{Na}^{+}, \mathrm{Mg}^{2+}, \mathrm{K}^{+}$, and $\mathrm{Ca}^{2+}$ were analyzed by flame absorption spectrometry.

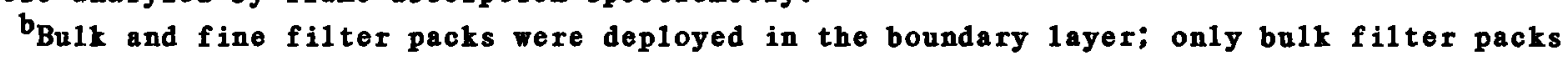
were deployed in the free troposphere. 


\section{RESULTS AND DISCUSSION}

3.1. Distributions of HC1 in the Western NAO Troposphere

The vertical distributions of $\mathrm{HC} 1$ measured near the U.S. east coast and in the vicinity of Bermuda are summerized in Figure 1. Given uncertainties in the quality of the various data sets, HCl estimated from collections for bolk and fine filter packs are depicted separately. Concentrations of sea salt in the FT were below detection 1 imits, and it is therefore unlikely that reactions involving sea salt were a major source of bias for these higher altitude measurements of BC1 osing bulk filter pack samplers. In 1 ight of the assessment of data quality (soe appendix), we believe that distributions of ambient concentrations of $\mathrm{HCl}$ in the lower BL (a1titude $152 \mathrm{~m}$ ) are probably best represented by the lower concentrations measured with the fine filter packs on the ircraft. Near-surface measurements using bulk filter packs aboard the ship may have overestimated ambient concentrations by a factor of approximately 2 .
The observed distributions of concentrations (Figure 1) indicate marked vertical and horizontal variability. Concentrations of $\mathrm{HC} 1$ were highest near the surface and decreased rapidy with altitude. This distribution parallels the vertical distribution of sea-salt aerosol (Table 2). Concentrations of HC1 near the east coast were approximately 2 times greater at all altitudes relative to corresponding values near Bermuda. With the exception of shipboard measurements on Ja1y 22, a11 concentrations greater than 0.75 ppbv were observed on the first day of samp1ing when $1 \mathrm{arge}$ anthropogenic influences were evident (see companion papers in this issue). The unusually high (greater than 1 ppbv) HCl concentrations observed on July 22 were also associated with anthropogenic emissions. Ship observations coupled with trajectory analyses and measurements of ${ }^{22} \mathrm{Rn}$ and graphitic carbon indicate that heavy ship traffic in the vicinity of the research vessel significantly impacted the local atmosphere [Hansen ot a 1.., 1990]. Like the situation in the immediate vicinity of the east coast, combustion products were associated

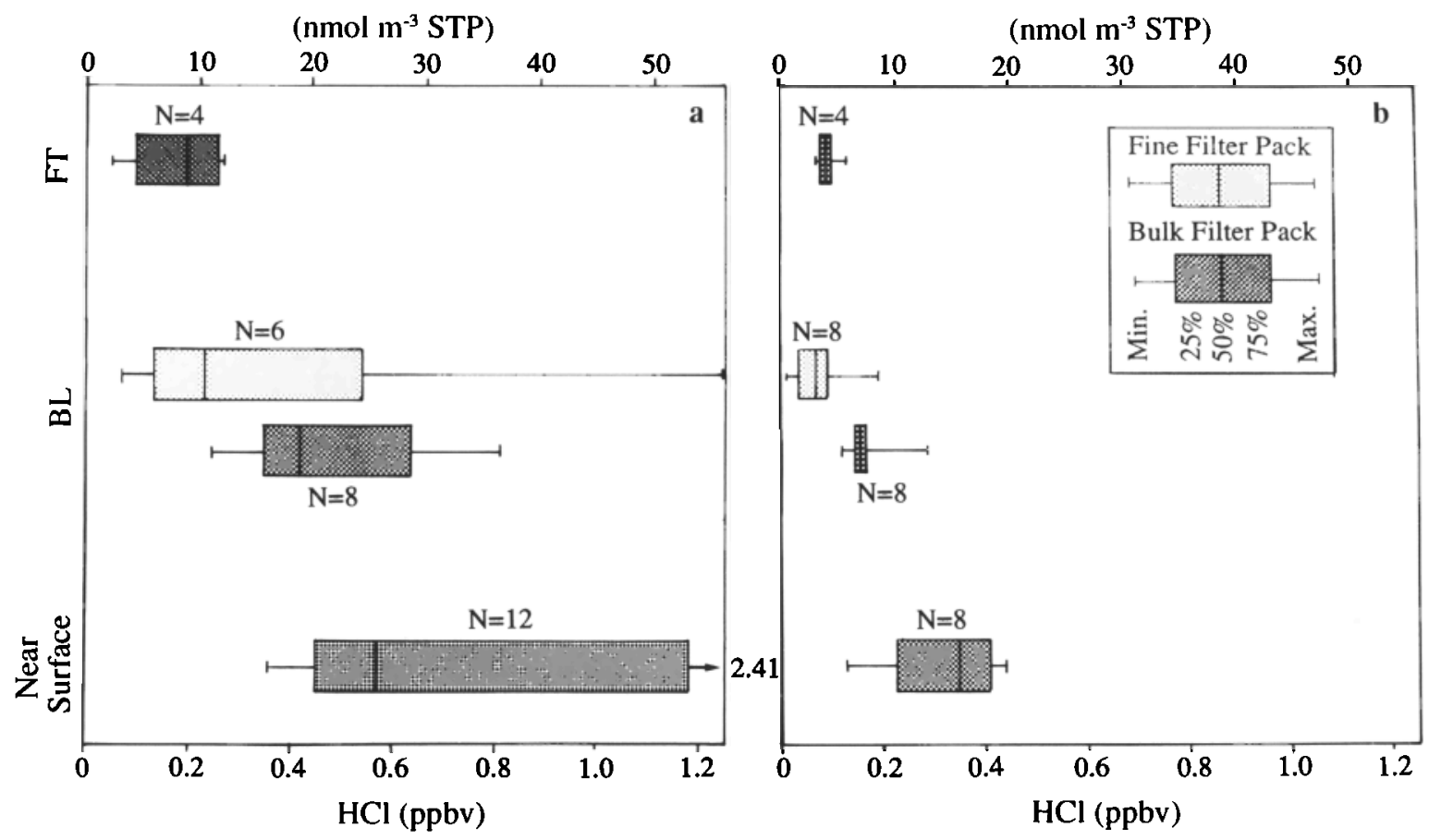

Fig. 1. Distributions of HCI (a) near the east coast and (b) near Bermuda measured with the UVA/AQG filter pack samplers on the ship (indicated as near sorface) and on the aircraft in the boundary layer (BL) (152 $\mathrm{m}$ ) and in the froe troposphere (FT) (1676-2591 m). Data for fine and bolk filter packs are depicted separately. 
TABLE 2. $\mathrm{C1}^{-}$Loss From the Particulate Phase

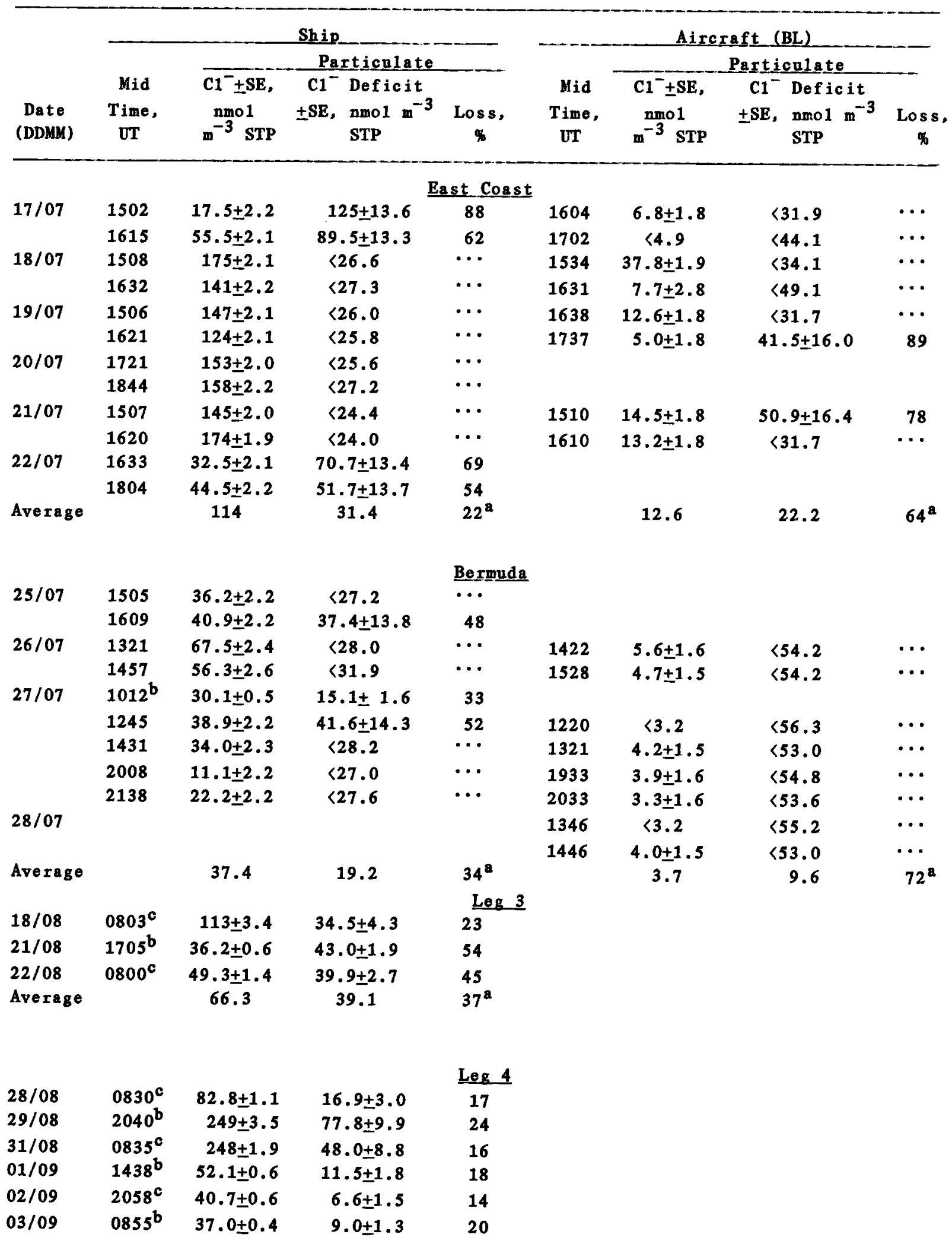


TABLE 2. (continued)

\begin{tabular}{|c|c|c|c|c|c|c|c|c|c|c|}
\hline \multirow[b]{3}{*}{$\begin{array}{c}\text { Date } \\
\text { (DDMM) }\end{array}$} & \multicolumn{5}{|c|}{ Ship } & \multicolumn{5}{|c|}{ Aircraft (BL) } \\
\hline & \multirow[b]{2}{*}{$\begin{array}{l}\text { Mid } \\
\text { Time, } \\
\text { UT }\end{array}$} & \multicolumn{4}{|c|}{ Particn1ate } & \multirow[b]{2}{*}{$\begin{array}{l}\text { Mid } \\
\text { Time, } \\
\text { UT }\end{array}$} & \multicolumn{4}{|c|}{ Particulate } \\
\hline & & $\begin{array}{l}\mathrm{C}^{-} \pm \mathrm{SE} \\
\text { nmol } \\
\mathrm{m}^{-3} \text { STP }\end{array}$ & $\begin{array}{r}\mathrm{C1}^{-} \\
\pm \mathrm{SE}\end{array}$ & $\begin{array}{l}\text { Deficit } \\
\text { nmol } \mathrm{m}^{-3} \\
\text { STP }\end{array}$ & $\begin{array}{c}\text { Loss, } \\
\%\end{array}$ & & $\begin{array}{l}\mathrm{C1}^{-} \pm \mathrm{SE}, \\
\text { nmo1 } \\
\mathrm{m}^{-3} \mathrm{STP}\end{array}$ & $\begin{array}{r}\mathrm{C1}^{-} \\
\pm \mathrm{SE}\end{array}$ & $\begin{array}{l}\text { Deficit } \\
\text { nmo1 } \mathrm{m}^{-3} \\
\text { STP }\end{array}$ & $\begin{array}{c}\text { Loss, } \\
\%\end{array}$ \\
\hline \multicolumn{11}{|c|}{ Leg 4 (continued) } \\
\hline $05 / 09$ & $0322^{c}$ & $40.8 \pm 1.1$ & & $.8 \pm 1.1$ & -16 & & & & & \\
\hline $05 / 09$ & $1524^{b}$ & $21.4 \pm 0.3$ & & $3.6 \pm 1.1$ & 29 & & & & & \\
\hline Average & & 96.5 & & 21.3 & $18^{a}$ & & & & & \\
\hline
\end{tabular}

Unless otherwise noted, shipboard data correspond to samples from the UVA/AQG bulk filter pack. SE, standard error.

average percent losses are calculated from average concentrations of particulate $1^{-}$ and average $\mathrm{Cl}^{-}$deficits for the specified data sets. Individual measurements below detection 1 imits were included in the calculation of average concentrations.

${ }^{b}$ Sum of concentrations for stages 1 through 4 of AOML cascade impactor.

c Sum of concentrations for stages 0 through 4 of URI cascade impactor.

with elevated concentrations of $\mathrm{HCl}$ and proportionate losses of particulate $\mathrm{Cl}^{-}$ from the sea-salt aerosol (see next section).

\subsection{Re1ationships Between Particulate nss $\underline{\mathrm{Cl}^{-}}$and $\mathrm{HCl}$}

Virtually all concentrations of particulate nss $\mathrm{C1}^{-}$measured from the aircraft in the BL were below system detection 1imits, thereby precluding a direct comparison with HC1. An initial inspection of data generated with the UVA/AQG samp1er on the ship indicates reasonably good agreement between the paired observations and a 1 to -1 ine (Figure 2). Similar correlations between $\mathrm{HC} 1$ and nss $\mathrm{C1}^{-}$have been reported previously for marine air masses in Ca1ifornia [Wa11 et a1.. 1988]. Observations from both of these investigations are consistent with the hypotheses that sea-salt aerosol is the primary source for HC1 in the marine BL and that HC1 and sea-salt aerosol have similar atmospheric 1 ifetimes against deposition, as was suggested by Kritz and Rancher [1980].

Distinct patterns become evident when the paired data are partitioned into subgroups based on chemical and meteorological analyses. Four samples were collected on Ju1y 17 and 22 in air masses exhibiting significant anthropogenic influences

(Figure 2, solid squares). Within analyt- ical uncertainties, the concentrations of HCI measured during these periods were directly proportional to the corresponding $\mathrm{Cl}^{-}$deficits for the particulate phase. Similarly, six of eight paired measurements in the vicinity of Bermuda (Figure 2, open circles) indicate direct proportionality between $\mathrm{HC} 1$ and $\mathrm{Cl}^{-}$deficits. In contrast, eight data pairs for cleaner maritime air sampled near the east coast (Figure 2, solid circles) exhibited consistently higher concentrations of HCl relative to $\mathrm{Cl}^{-}$deficits. The ratio of arithmetic averages is 4.5 to 1.0 . We recognize that all of these nss $\mathrm{C}_{1}^{-}$concentrations were below analytical detection 1 imits, but the consistency of the pattern cannot be dismissed on this basis alone. If the data are unbiased, and if real proportionality exists in the ambient $B L$, these paired measurements world be distributed around the 1 to -1 ine. Assuming that $\mathrm{HC} 1$ does originate with seasalt aeroso1, these data suggest that the atmospheric 1 ifetime of HC1 against deposition may be considerably longer than that of sea-salt aerosol in southeasterly maritime flow near the U.S. east coast during the summer. This is not an unexpected result given the relatively high concentrations of sea-salt aerosol observed during this period (Table 2). Such concentrations would be associated with larger median particle sizes and greater deposition velocities for sea-salt 


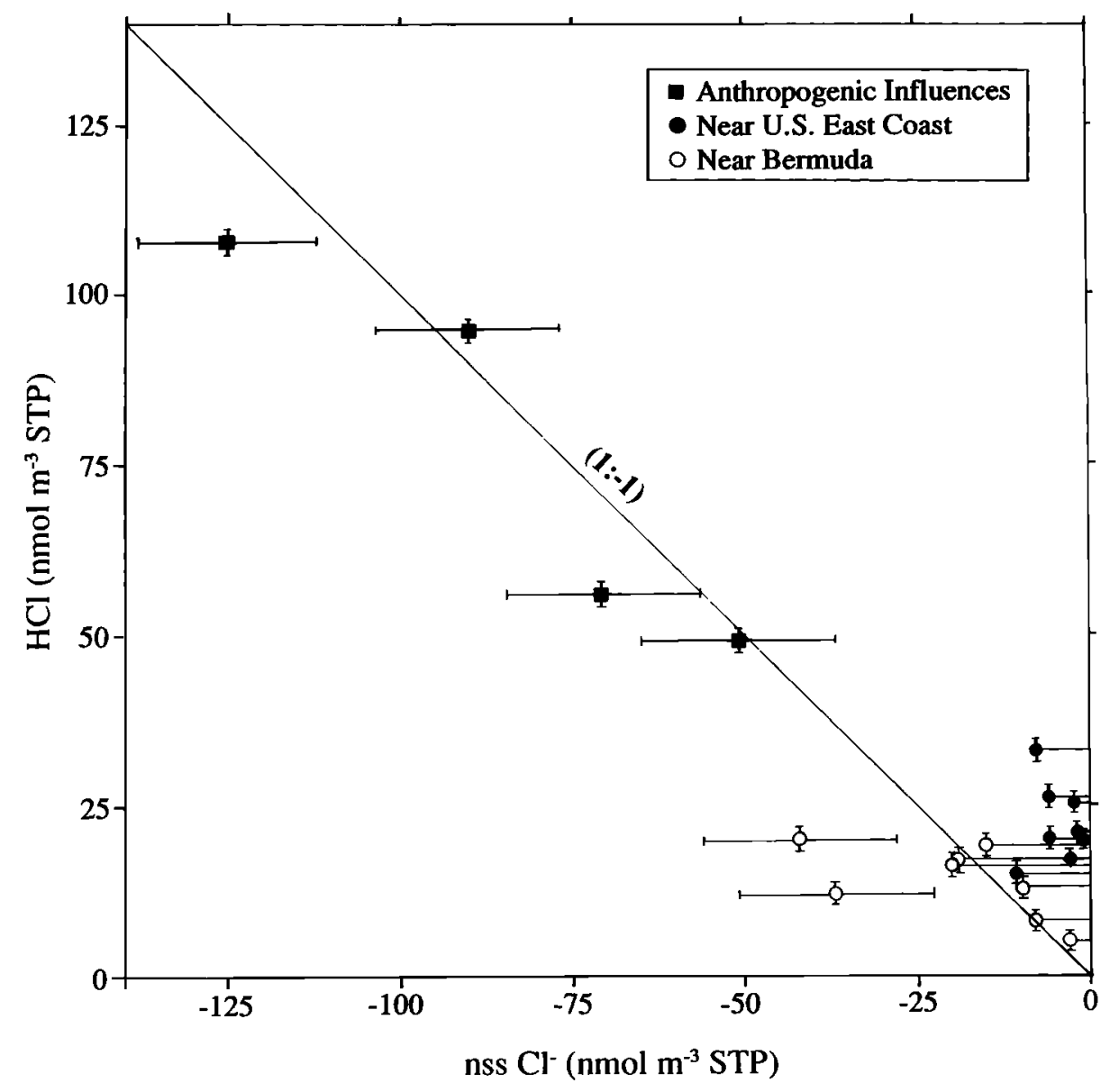

Fig. 2. Comparison between HC1 and nss C1- measured simultaneously with the UVA/AQG bulk filter pack sampler on the ship.

aerosol relative to most other periods during the cruise.

The analysis presented above suggests that the atmospheric lifetime of BC1 against deposition may be longer than that of sea-salt aerosol in some marine airmasses. The presence of a possible artifact (see appendix) which may have caused overestimates of ambient $\mathrm{HCl}$ and $\mathrm{Cl}^{-}$deficits does not seriously compromise the above assessment, since both constituents should be affected equaliy. The absolute magnitudes of the observed relationships would, however, be impacted by such an artifact.

\subsection{Magnitude of $\mathrm{C1}^{-}$Loss. From the} Particn1ate Phase

The magnitudes of $\mathrm{Cl}^{-}$deficits observed for data generated with the UVA/AQG filter packs on the aircraft and the ship and with the AOML and URI cascade impactors on the ship are summarized in Table 2. Data for the AOML filter packs were excluded because the inlet discriminated against large particles, resulting in 1 arge underestimates of sea-salt aerosol mass (see section 2). Data for the AOML hivol were a 1 so excluded because we expect that larger pressure drops and higher sample loadings contributed to larger artifacts relative to the UVA/AQG filter packs. We emphasize that nss $\mathrm{Cl}^{-}$data generated with the bulk filter packs are likely to be biased and should be considered as upper limits for actual C1 losses.

Large anthropogenic influences observed on July 17 and 22 were associated with higher absolute and percentage $\mathrm{Cl}^{-}$deficits relative to other samples collected from the ship near the east coast. Between 54 and $88 \%$ of sea-sa1t $\mathrm{C1}^{-}$was lost from near-surface aerosol during these 
episodes. From Jaly 19 to 22, relative1y clean maritime air was sampled from the ship [Stunder et 1., 1990; Hansen et a1., 1990]. Some of the highest sea-salt concentrations (Table 2) and lowest $\mathrm{Cl}^{-}$deficits (average $=6.1$ nmol $\mathrm{m}^{-3}$ STP; $N=6$ ) observed during the cruise were associated with these conditions. Resolution for nss $\mathrm{Cl}^{-}$from the aircraft was 1 imited, but mean values near the east coast indicate that the absolute concentrations of $\mathrm{Cl}^{-}$ (22.2 nmo1 $\mathrm{m}^{-3}$ STP) $10 \mathrm{st}$ from sea-salt aerosol at 152 m were similar to those lost from near surface aerosol ( 31.4 nmol $\mathrm{m}^{-3}$ STP). Large differences in the percentages lost result in part from relatively lower absolute concentrations of sea salt at the higher altitude (Table 2). If there is a significant time dependence on the magnitude of $\mathrm{Cl}^{-}$release, the older average age of sea-salt aerosols at higher altitude may contribute to larger percentage deficits observed in aircraft samples.

Relative to the east coast, lower concentrations of sea-salt aerosol and $\mathrm{C1}^{-}$ deficits were measured from the ship near Bermuda. Average values for aircraft samples suggest that major features of the vertical distributions near Bermada were similar to those observed near the east coast. Concentrations of sea-salt aerosol decreased, and percentages of $\mathrm{Cl}^{-}$lost from the aerosol increased with altitude.

The highest average $\mathrm{C1}^{-}$deficits (39.1 nmo1 $\mathrm{m}^{-3}$ STP) and percentage losses (37\%) were observed from the ship during $1 \mathrm{eg} 3$ between Iceland and the Azores. Trajectory classifications based on the origin of airmasses [Stunder et a1., 1990] suggest that anthropogenic sources are probably not related directly to the observed losses of $\mathrm{C1}^{-}$during the se sampling periods. Relative to other legs of the cruise, high concentrations of sea salt, low $\mathrm{Cl}^{-}$deficits and 1 ow percentage losses were observed during 1 eg 4 (Table 2). Assuming that the $\mathrm{C1}^{-}$lost from seasalt aerosol generated equivalent concentrations of HC1 and that the lifetime of BC1 in the BL is at least as long as that of sea-sa1t aerosol, the $\mathrm{C1}^{-}$deficits measured on legs 3 and 4 correspond to minimum mean estimates for HC1 of $0.9 \mathrm{ppbv}$ and 0.5 ppbv, respectively.

\subsection{Assessment of Hypothesized} Mechanisms for C1 Loss From Particles

The two major hypothesized mechanisms by which $\mathrm{Cl}^{-}$is released from sea-salt aeroso1 involve acid-base desorption (reac- tions (1) and (2)), and reactions between nonacidic $N$ gases and sea-salt aerosol (reactions (3), (4), and (5)). If acidbase reactions were the principal mechanism of release, $\mathrm{Cl}^{-}$deficits in coarse fractions of aerosols would be less than the corresponding sums of anions from $\mathrm{H}_{2} \mathrm{SO}_{4}$ and $\mathrm{HNO}_{3}$ because the aerosol, which is initially alkaline, must first be acidified before desorption can occur [Brimblecombe and Clegg, 1988]. Taking account also of acid nentralization by $\mathrm{NH}_{3}$, this relationship can be expressed on an equivalence basis as follows:

$\left[-n s s \mathrm{Cl}^{-}\right]<\left(\right.$[nss $\left.\left.\mathrm{SO}_{4}{ }^{2-}\right]+\left[\mathrm{NO}_{3}{ }^{-}\right]-\left[\mathrm{NH}_{4}{ }^{+}\right]\right)$

If the alternative hypothesis involving nonacidic $N$ gases were the primary mechanism of release, then $\mathrm{C1}^{-}$deficits in coarse fractions would equal those of coarse particulate $\mathrm{NO}_{3}{ }^{-}$as follows:

$\left[-\right.$ nss $\left.\mathrm{Cl}^{-}\right]=\left[\mathrm{NO}_{3}{ }^{-}\right]$

Each of these relationships represents a maximum estimate for the amount of $\mathrm{C} 1$ desorbed by the corresponding mechanism, since neither is utually exclusive of the other.

Relationships (6) and (7) were evaluated with both the AOML and URI data sets for the cascade impactors (Figure 3a). Eleven of the 12 samples revealed losses of $\mathrm{Cl}^{-}$from the particulate phase (i.e., positive $\mathrm{Cl}^{-}$deficits). Results of the Wilcoxon Signed Ranks Test indicate that $\mathrm{C1}^{-}$deficits in coarse fractions (greater than $50 \%$ aerodynamic cut radius of $0.5 \mu \mathrm{m}$ ) were significantly greater (alpha=0.05) than both the concentrations of anions from unneutralized $\mathrm{H}_{2} \mathrm{SO}_{4}$ and $\mathrm{HNO}_{3}$ in the coarse mode and the concentrations of coarse $\mathrm{NO}_{3}{ }^{-}$. Acid-base desorption reactions could account for maxima of between less than 1 and $57 \%$ of $C 1$ released from the particulate phase. Reactions involving $\mathrm{N}$ gases (including $\mathrm{HNO}_{3}$ ) and sea-salt aerosol could account for maxima of between 4 and $47 \%$ of the $\mathrm{C}^{-}$loss. Minima of between 43 and $96 \%$ of observed $\mathrm{C1}^{-}$ deficits could not be accounted for by the combined effect of these major hypothesized mechanisms. We note here that simi1ar relationships among the products of reactions (1) through (5) were observed over the tropical Pacific Ocean between $85^{\circ}$ and $180^{\circ}$ longitude during a JanuaryFebruary 1990 shipboard study conducted by the NOAA AOML (A. A. P. Pszenny, nnpub- 

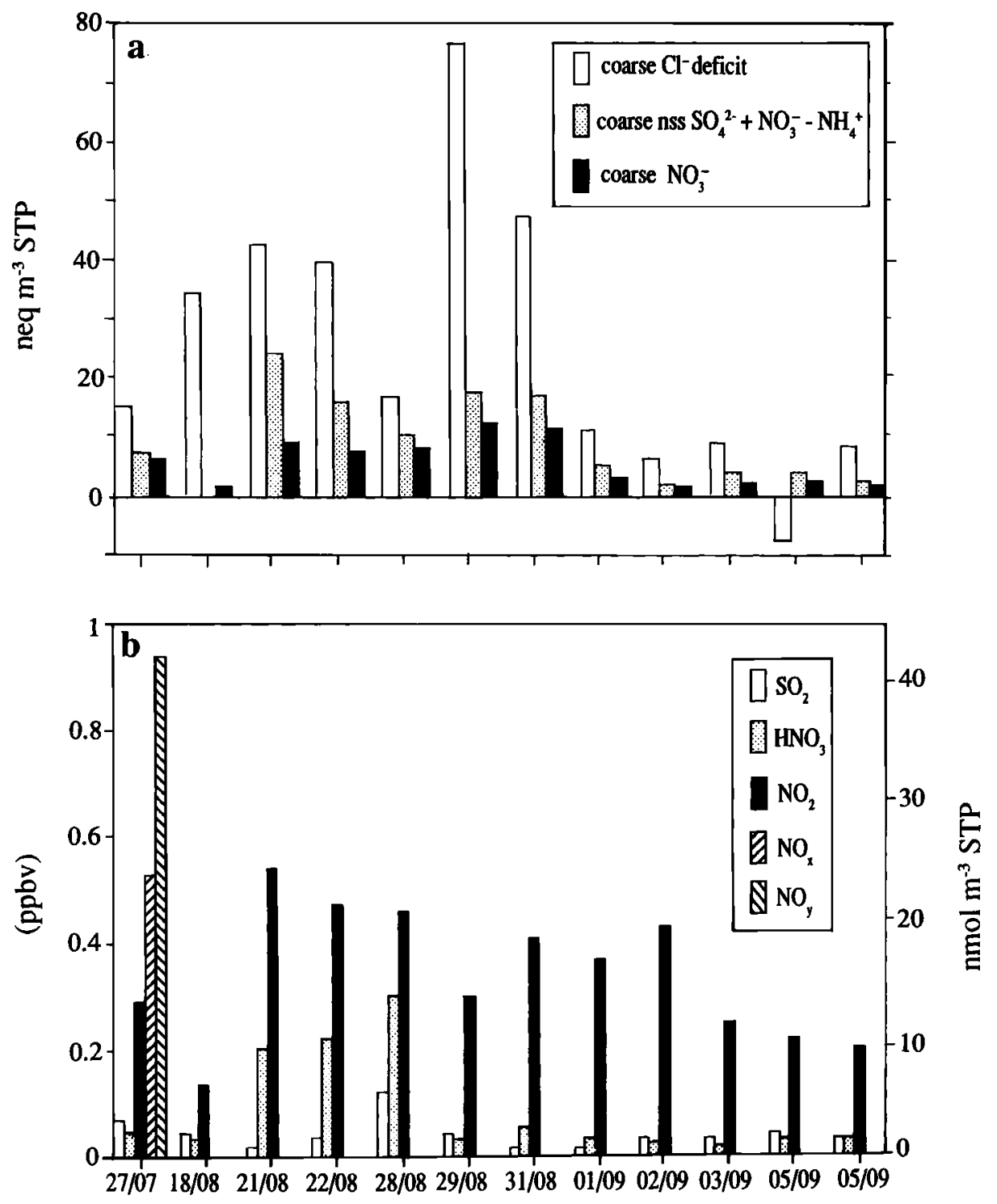

Mid Sampling Date (DD/MM)

Fig. 3. (a) Comparisons among the sums of $\mathrm{Cl}^{-}$deficits, anions from strong acids (approximated as nss $\mathrm{SO}_{4}{ }^{2-}+\mathrm{NO}_{3}{ }^{-}-\mathrm{NH}_{4}{ }^{+}$), and $\mathrm{NO}_{3}{ }^{-}$in the coarse stages of AOML ( 1 through 4 ) and URI ( 0 through 4) cascade impactors operated on the ship, and (b) corresponding concentrations of $\mathrm{SO}_{2}$ and odd $\mathrm{N}$ gases measured on the ship during overlapping but not entirely concurrent sampling periods. $\mathrm{SO}_{2}$ and $\mathrm{HNO}_{3}$ were measured with the $\mathrm{AOML}$ filter pack samplex. $\mathrm{NO}_{2}$, $\mathrm{NO}_{\mathrm{z}}$, and $\mathrm{NO}_{\mathrm{y}}$ data were provided by D. Hastie (personal communication, 1990). (See Hastie et a1. [1990] for methodological details).

1 ished data, 1990). These new observations indicate that the implications of our analysis are not restricted to the NAO but may apply to the marine BL on a global scale.
Concentrations of potential reactart and product gases were averaged over each sampling interval for the cascade impactors and are plotted in Figure $3 b$.

Because of the possibility for artifacts 
resulting from gas-to-particle reactions on bulk prefilters (see appendix), $\mathrm{SO}_{2}$ and $\mathrm{HNO}_{3}$ concentrations measured with the AOML filter pack are considered lower estiwates. The highest concentrations of $\mathrm{NO}_{3}{ }^{-}$ and four of the five highest $\mathrm{Cl}^{-}$deficits measured on coarse impactor stages were observed for the five samples collected between Angust 21 and 31 . The first three of these samples corresponded to the three highest mean $\mathrm{HNO}_{3}$ concentrations measured during impactor sampling. The other two samples were collected during the period of highest sea-salt concentrations encountered during the cruise (Table 2). Significant concentrations of Saharan dust were also apparent in conjunction with these two samples. Higher concentrations of sea-sa1t aerosol would be expected to scavenge $\mathrm{HNO}_{3}$ more efficiently from the ambient $B L$, causing a shift in partitioning toward the particulate phase. The decrease in $\mathrm{HNO}_{3}$ between August 28 and 29 (11.6 nmo $1 \mathrm{~m}^{-3}$ STP) is in the range of the observed increase in coarse $\mathrm{NO}_{3}^{-}$(4.4 nmol $\mathrm{m}^{-3}$ STP). By comparison, the $\mathrm{Cl}_{1}^{-}$deficit in coarse fractions increased by 60.9 nmo 1 $\mathrm{n}^{-3}$ STP over the same period, indicating that only a minor fraction of the volatilized $\mathrm{Cl}$ could be explained by increased scavenging of $\mathrm{HNO}_{3}$. The average concentrations of $\mathrm{NO}_{2}$ during impactor sampling intervals were 1 ess variable relative to $\mathrm{HNO}_{3}$ and coarse particulate $\mathrm{NO}_{3}{ }^{-}$[Hastie et a1., 1990]. There were no obvious relationships between $\mathrm{NO}_{2}$ and $\mathrm{Cl}_{1}^{-}$deficits in coarse fractions. NO and $\mathrm{NO}_{\mathrm{y}}$ data were available for only the first cascade impactor sampling period.

Mean concentrations of $\mathrm{SO}_{2}$ for 11 of the 12 sampling intervals were less than 2.7 nmol $\mathrm{m}^{3}$ STP. These concentrations were similar to those for nss $\mathrm{SO}_{4}$ - which averaged $2.8 \mathrm{nmol} \mathrm{m}^{-3}$ STP in the coarse fractions of all samples. Considering the short atmospheric 1 ifetime of sea-salt aerosol [e.g., Kritz and Rancher, 1980], these measurements of $\mathrm{SO}_{2}$ and coarsefraction nss $\mathrm{SO}_{4}{ }^{2-}$ suggest that $\mathrm{SO}_{2}$ has a short 1 ifetime in the marine $B L$ against scavenging by sea-salt aerosol (also see Sievering et a1. [1991]). If sufficient acidity is present to lower the aerosol pH below 3.0, HC1 volatilization would be expected from reaction (2) [Brimblecombe and Clegg, 1988].

The large $\mathrm{C1}^{-}$deficits observed in the impactor data were not balanced on an equivalent basis by measured anions. These results suggest the possibility that $\mathrm{Na}^{+}$was systematically overestimated, or that $\mathrm{Cl}^{-}, \mathrm{NO}_{3}^{-}$, or $\mathrm{SO}_{4}{ }^{2-}$ were systematically underestimated, by large factors. Quality assurance assessments indicate, however, that such large errors were unlikely. Two sets of spike recovery tests for major seawater species were performed in the laboratory at AOML on both Whatman 41 and $P a 11$ flex quartz filters. The results of one experiment indicated an approximate $90 \%$ recovery of $\mathrm{SO}_{4}{ }^{2-}$, and both experiments indicated $\mathrm{Mg}^{2+}$ recoveries of only 80 to $90 \%$ from Whatman 41 filters. Otherwise, a11 ions were recovered from both filter types with efficiencies not significantly different from 100\%. Additional experimgnts are planned to confirm whether $\mathrm{SO}_{4}{ }^{2-}$ recoveries from Whatman 41 are indeed significantly less than 100\%, but the magnitude of possible bias from incomplete recovery is small relative to the concentrations of missing anions in samples.

Alternative1y, unmeasured anions may be important chemical constituents of coarse marine aerosol fractions. $\mathrm{HCO}_{3}^{-}$is one possibility, but estimation of ${ }^{\left[\mathrm{HCO}_{3}\right.}{ }^{-}$] is precluded by lack of reliable $\mathrm{H}^{+}$measurements for the cascade impactor samples. Few experimental investigations of the acid-base chemistry of coarse sea-salt aerosol have been conducted. On the basis of 1 imited data [e.g., Wink]er, 1980 , 19861, however, it appears that the pH of sea-salt aerosol is typically in the range of 7.0 to 9.0. This implies that $\mathrm{BCO}_{3}{ }^{-}$ may contribute significantly to the ionic strength of sea-salt aerosol and, if so, may represent the missing anions in our samples. If this is the case, it has important implications for the mechanism by which C1 is released from the aerosol. Essentially no HC1 will volatilize directly from sea-salt aerosol in this $p H$ range. Indeed, neutral or alkaline aerosol would represent a net sink for atmospheric HC1. If sea-sa1t aerosol does scavenge HC1 from the atmosphere, then the release rates of other volatile Cl compounds from the aerosol would be greater than those inferred from measured $\mathrm{Cl}^{-}$ deficits, for which a conservative $C_{1}$ source based on the seawater ratio with $\mathrm{Na}^{+}$is assumed. This point is discussed in section 4 .

In summary, the analysis presented above does not provide clear evidence supporting either of the major hypothesized mechanisms by which C1 is released from sea-sa1t aeroso1, although such reactions are not precluded by onr observations. Our measurements of the products 
of reactions (1) through (5) indicate, however, that an average of only $38 \%$ of the measured $\mathrm{C}^{-}$lost from the particles could be accounted for by these niechanisms. This suggests that other processes may be occurring that also lead to Cl loss from sea-salt aerosol.

\subsection{A Photochemica1 $\mathrm{C1}_{1}^{-}$Loss. Mechanism.}

Petriconi and Papee [1972] observed the volatilization of $\mathrm{Cl}^{i}$ and $\mathrm{NO}_{\mathrm{x}}$ from concentrated seawater- $\mathrm{NaFO}_{3}$ solutions irradiated with naturs. sunlight under ambient air conditions. Ionic strengths and concentrations in the solutions were similar to those expected for natural sea-salt aerosols in the marine BL [Brimblecombe and $\mathrm{Clegg}, 1988$ ]. The rate of $\mathrm{Cl}^{j}$ volatilization increased with increasing $\mathrm{NaNO}_{3}$ concentrations, suggesting a radical mechanism initiated by photolytic reduction of $\mathrm{NO}_{3}{ }^{-}$[Zafiriou and True, 1979]. Significant $\mathrm{Cl}_{\mathrm{i}}$ volatilization was still observed in the absence of $\mathrm{NaNO}_{3}$, however, and was attributed by Petriconi and Papeo [1972] to an alternate $\mathrm{Cl}_{1}$ oxidation mechanism initiated by photolysis of $\mathrm{O}_{3}$ in the ambient air. Recently, smog chamber experiments by Zetzsch et al. [1988] and Behnke and Zetzsch [1989] have documented the production of $\mathrm{Cl}_{2}$ from irradiation of moist artificial $\mathrm{NaCl}$ aerosols in the presence of $\mathrm{O}_{3}$. The production of $\mathrm{Cl}_{2}$ was al so observed in the dark but was slower.

Behnke and Zetzsch [1989] proposed that the production of $\mathrm{Cl}_{2}$ in their experiments resulted from oxidation of $\mathrm{Cl}^{-}$by ${ }^{\circ} \mathrm{OH}_{\text {(aq) }}$
[Jayson et a1.. 1973; McE1roy, 1990], where ${ }^{\circ} \mathrm{OH}(\mathrm{aq})$ can be generated in a number of ways following photolysis of $\mathrm{O}_{3}$

[Chameides and Davis, 1982; Jacob, 1986]. For example,

$$
\begin{aligned}
& \mathrm{O}_{3(\mathrm{~g})}+\mathrm{hv} \rightarrow \mathrm{O}_{2(\mathrm{~g})}+O\left({ }^{1} \mathrm{D}\right)(\mathrm{g}) \\
& \left.O{ }^{1} \mathrm{D}\right)_{(\mathrm{g})}+\mathrm{H}_{2} \mathrm{O}(\mathrm{g}) \rightarrow 2 \cdot \mathrm{OH}(\mathrm{g}) \\
& \cdot \mathrm{OH}_{(\mathrm{g})} \longrightarrow \cdot \mathrm{OH}_{(\mathrm{a} \mathrm{q})} \\
& \cdot \mathrm{OH}(\mathrm{aq})+\mathrm{Cl}^{-}-\rightarrow \cdot \mathrm{ClOH}^{-} \\
& \cdot \mathrm{ClOH}^{-} \longleftrightarrow \mathrm{Cl}_{(\mathrm{aq})}+\mathrm{OH}^{-} \\
& \mathrm{C} 1 \cdot{ }_{(\mathrm{aq})}+\mathrm{C1}^{-} \longleftrightarrow->\cdot \mathrm{Cl}_{2}{ }^{-} \\
& \cdot \mathrm{Cl}_{2}{ }^{-}+\cdot \mathrm{Cl}_{2}{ }^{-} \rightarrow \mathrm{Cl}_{2}(\mathrm{~g})+2 \mathrm{Cl}^{-}
\end{aligned}
$$

The recombination of $\cdot \mathrm{Cl}_{2}{ }^{-}$is quenched in dilute solutions because of $\mathrm{Cl}^{\circ}$ (aq) hydrolysis [McE1roy, 1990], but it may be efficient in concentrated solutions where the $\mathrm{C} 1 \cdot(\mathrm{aq})^{/} \mathrm{Cl}_{2}{ }^{-}$equilibrium (reaction (13)) is shifted toward ${ }^{\circ} \mathrm{C}_{2}{ }^{-}$. The mechanism (8)-(14) imp1ies an increase in $\mathrm{Cl}_{2}$ production with increasing acidity, due to (12), which is consistent with the pH dependence of $\mathrm{Cl}^{\mathrm{i}}$ release observed by Petriconi and Papee [1972].

A photolytic source of $\cdot \mathrm{OH}_{(\mathrm{aq})}$ cannot, however, explain the production of $\mathrm{Cl}_{2}$ observed by Behnke and Zetzsch [1989] in the dark. Possibly, ${ }^{\circ} \mathrm{OH}_{(\mathrm{g} q)}$ could be produced by reactions of $\mathrm{O}_{3}$ at electron donor sites on the aerosol surface [Heikes, 1984]. Alternatively, direct surface reaction of $\mathrm{O}_{3}$ with $\mathrm{Cl}^{-}$may occur [Behnke and Zetzsch, 1989]:

$2 \mathrm{Cl}^{-}+\mathrm{O}_{3(\mathrm{p})} \stackrel{\mathrm{H}_{2} \mathrm{O}}{---} \mathrm{Cl}_{2(\mathrm{~g})}+2 \mathrm{OH}^{-}+\mathrm{O}_{2(\mathrm{~g})}$

Note that the stoichiometry of (15) is the same as that of the ensemble of (8)-(14). Both involve the loss of one $\mathrm{O}_{3}$ molecule per $\mathrm{Cl}_{2}$ molecule produced, and both involve production of alkalinity. $\mathrm{HCO}_{3}{ }^{-}$ would replace the $\mathrm{Cl}^{-}$lost from the seasalt aerosol, thus accounting for the missing anions in our samples (see section 3.4).

\subsection{Geochemical Cycling of Reactive C1} in the Marine BL

Losses of particulate $\mathrm{C1}^{-}$observed during GCE/CASE/WATOX include typically $10 \mathrm{nmol}^{-3} \operatorname{STP}(0.25 \mathrm{ppbv})$, at minimum, which could not be attributed to acid displacement reactions. Following section 3.5, we assume as a working hypothes is that these losses reflect the volatilization of $\mathrm{Cl}_{2}$ by a mechanism with the stoichiometry of (15). Photolysis of $\mathrm{Cl}_{2}$ in the daytime takes place on a time scale of minutes and produces $\mathrm{C} 1^{\circ}$, which reacts rapidiy to yield $\mathrm{HCl}$ and $\mathrm{ClNO}_{3}$ (the latter via (10). As was discussed in section 3.4, the low concentrations of coarse particulate $\mathrm{NO}_{3}^{-}$(Figure 3 ) suggest that reactions involving $\mathrm{ClNO}_{3}$ are probably of minor importance. HC1 is scavenged efficient1y by aeroso1 [Watson et a1., 1990], closing the C1 cycle (Figare 4). We estimate a time scale of the order of $10 \mathrm{~min}$ for scavenging of $\mathrm{BC} 1$ by sea-salt aerosol in surface air based on a calculation of gas-to-aerosol fluxes [Fuchs and Sutugin, 1971] and, assuming negligible vapor, a sticking coefficient of 0.15 [Hatson et 


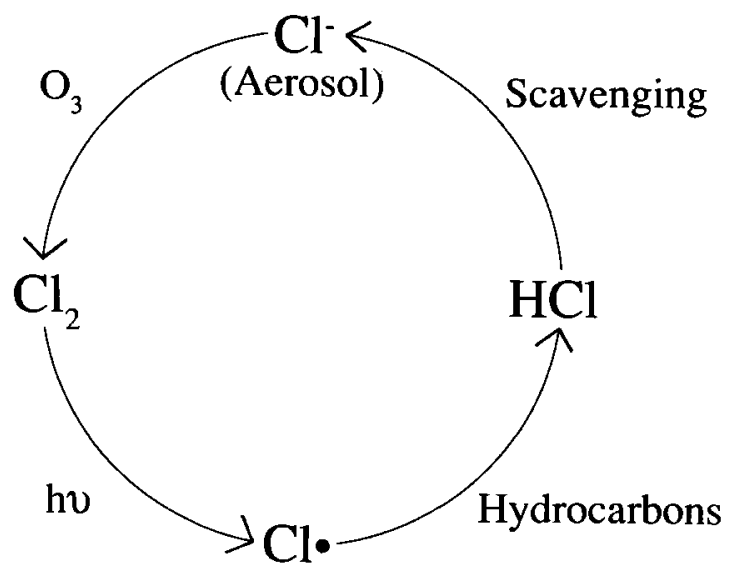

Fig. 4. Hypothesized geochemical cycle of reactive inorganic chlorine in the marine boundary 1 ayer.

a1., 1990], and a sea-sa1t aeroso1 mass concentration of $10 \mu \mathrm{g} \mathrm{m} \mathrm{m}^{-3}$ [Pszenny et a1.. 1990b] with typical Junge-size distribution in the $0.1-$ to $10-\mu$ m radius range [Parungo et a1.. 1986]. We note that the scavenged HC1 would neutra1ize alkalinity generated via reaction (15), indicating that this sequence of chemical transformations is self-regulating with Iespect to the acid-base balance of seasa1t aeroso1. Steady state between $\mathrm{Cl}_{2}$ volatilization from the aerosol and scavenging of $\mathrm{HCl}$ by the aerosol imply a $\mathrm{Cl}_{2}$ source of the order of 1 ppbv $h^{-1}$ in the daytime.

From the mechanism described above, one would expect enhanced $\mathrm{Cl}^{-}$deficits in aerosols at night, when $\mathrm{Cl}_{2}$ is not photo1yzed. $\mathrm{Cl}^{-}$deficits measured using the AOML filter packs were examined for evidence of diel periodicity. Although data quality evaluations indicate that these nss $\mathrm{C}^{-}$data may be biased (see appendix), there is no reason to expect systematic differences in the relative magnitudes of bias between the daytime and nigbttime samples. The data set was partitioned into subsets that included $\mathrm{Cl}^{-}$deficits measured during three consecutive 12-hour sampling periods ( $A, B$, and $C$, respectively). The mean deficit for the two nightime or two daytime samples (A and $C$ ) in each subset was then subtracted from the deficit for the middle sample (B) to determine the net difference in desorbed $\mathrm{C1}^{-}$. If there was no diel periodicity in $\mathrm{C1}^{-}$deficits, the mean of these differences would be approximately 0 , and approximately equal numbers of positive and negative values would be observed. The net differences for all available data subsets are plotted in Figure 5 a for nighttime samples and in Figure $5 b$ for daytime samples. $\mathrm{Cl}^{-}$deficits during the night were greater than the corresponding daytime values for 9 of 12 data subsets (Figure 5a). The Wilcoxon Signed Ranks Test indicates that differences between these popnlations of nigbtine and daytine $\mathrm{C}^{-}$deficits were marginally nonsignificant at alpha=0.05. Given the high degree of variability in the data, it is possible the lack of significance simply reflects the sma1s number of paired observations. On average, the nighttime $\mathrm{Cl}^{-}$deficits for these samples were greater than daytime values by $8.6 \mathrm{nmol} \mathrm{m}^{-3}$ STP or $50 \%$. Conversely, $\mathrm{C1}^{-}$deficits for daytime samples were less than the corresponding nighttime values for 10 of 13 data subsets (Figure $5 b)$. These differences were significant at a $1 \mathrm{pha}=0.05$. Avezage daytime $\mathrm{C1}^{-}$deficits for these samples were less than nighttime values by 16.2 nmol $\mathrm{m}^{-3}$ STP or 70\%. The observed diel periodicity in the net flux of Cl from sea-salt aerosol is consistent with that expected from the proposed mechanism. We note that a similax analysis of day and night samples by Rancher and $K_{I}$ itz [1980] found no such periodicity.

\section{IMPLICATIONS FOR MARINE ATMOSPAERIC CHEMISTRY}

\subsection{Genera1. Considerations}

Our postulated explanation for the observed $\mathrm{C}^{-}$deficits (i.e., reaction (15) or the stoichiometric equivalent reactions (8)-(14)) would frovide a large sonrce of C1. to the marjne atmosphere. Such a source wonld in turn have major consequences for the oxidation of bydrocarbons and dimethyl sulfide (DMS), as oxidation of these compounds is typically 1-3 orders of magnitude faster by $\mathrm{C}^{\circ}$ than by ${ }^{\circ} \mathrm{OH}$. In polluted environments, the increased supply of peroxy radicals from the $\mathrm{Cl}^{-}+$ hydrocarbon reactions would promote photochemical $\mathrm{O}_{3}$ production. At the low $\mathrm{NO}_{\mathrm{x}}$ concentrations usually found in marine atmospheres, however, uptake of $\mathrm{O}_{3}$ by seasa1t aerosol wonld pxovide a net sink for $0_{3}$ because photochemical production is inefficient [e.g., Lin et al., 1983]. A challenging hypothesis emerges that the uptake of $\mathrm{O}_{3}$ by sea-salt aerosol could 

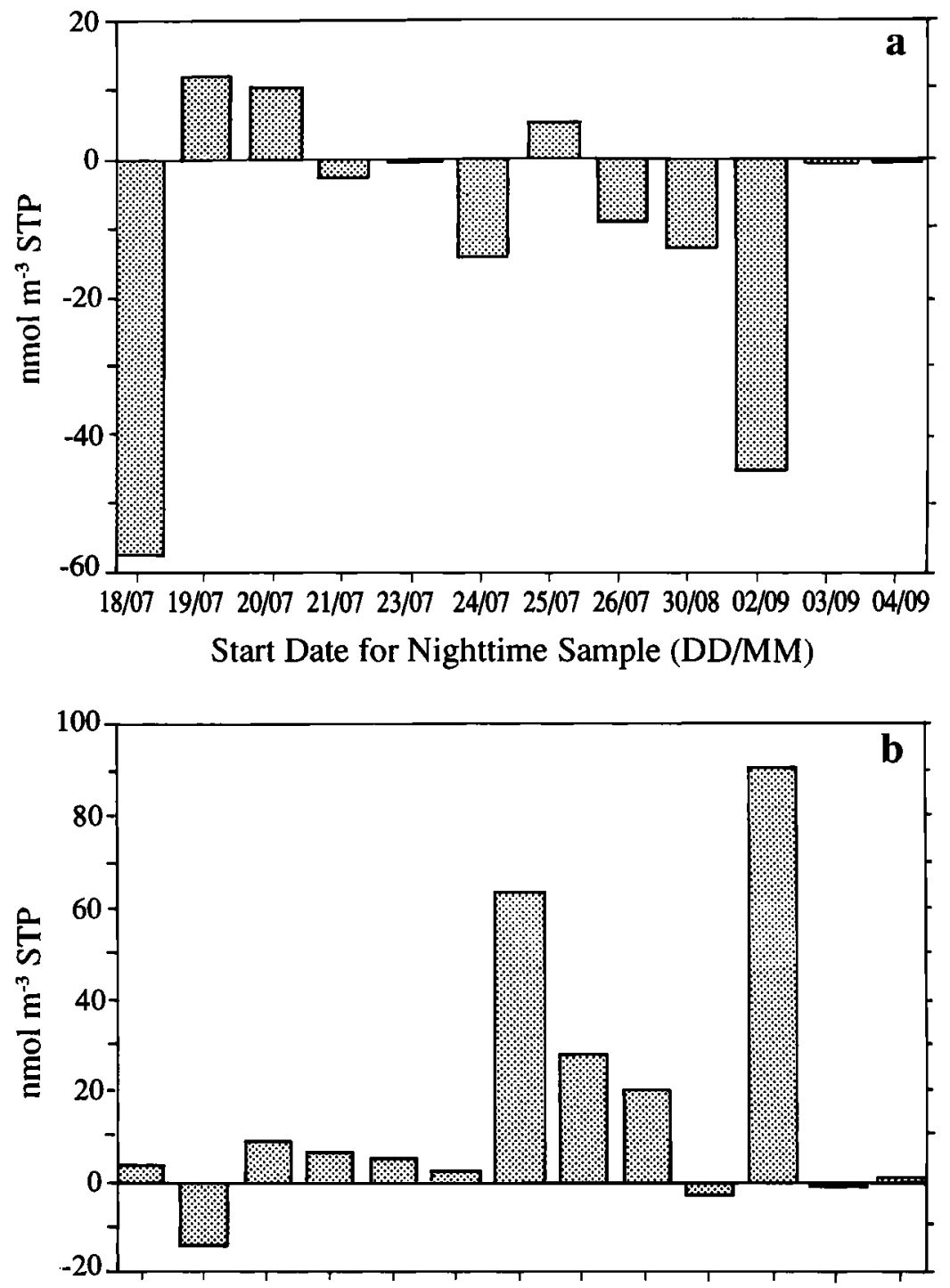

$19 / 07$ 20/07 21/07 24/07 25/07 26/07 02/08 04/08 22/08 28/08 02/09 03/09 04/09

Start Date for Daytime Sample (DD/MM)

Fig. 5. Die1 differences in nss $\mathrm{Cl}^{-}$measured with the AOLL filter pack sampler on the ship. (a) Non-sea-salt $\mathrm{Cl}^{-}$for nooturnal samples minus the mean $\mathrm{ns}$ $\mathrm{C1}^{-}$for diurnal samples collected during the preceding and following periods. (b) Non-sea-sa1t $\mathrm{Cl}^{2}$ for diurnal samples minus the mean $\mathrm{nss} \mathrm{Cl}^{-}$for nocturnal samples collected during the preceding and following periods.

explain the low concentrations of $\mathrm{O}_{3}$ observed in many ocean regions [Lidet a1.. 1983; Newe11 and Wu, 1985; Piotrowicz et a 1., 1986; 1990; Fishman et a1., 1990] and conld possibly provide a major global sirk for tropospheric $\mathrm{O}_{3}$.

Concentrations of $\mathrm{O}_{3}$ measured during GCE/CASE/WATOX a re interesting in this respect. Surface concentrations averaged 16 ppbv [Piotrowicz et a1., 1990] and increased significantly with altitude [Ray et a1.. 1990]. Corresponding surface concentrations of ${ }^{*} \mathrm{~N}_{\mathrm{T}}$ (NO + peroxyacy 1 nitrates) averaged $0 . \frac{7}{3}$ ppbv [Fastie et a1., 1990]. If NO acconnted for the major portion of " $\mathrm{No}_{z}$, as migbt be 
expected at the high temperatures of surface air, then vigorous $\mathrm{O}_{3}$ production would follow [Lin et a1., 1988]. The 1ow $0_{3}$ concentrations measured from the ship and from the aircraft in the lower BL $(150 \mathrm{~m})$ imply, however, that such production did not occur near the ocean surface. As discussed below, C1* chemistry may provide the explanation.

\subsection{Mode1 Simn1ations}

The sensitivity of atmospheric chemistry to the reactive $c 1$ source represented by reaction (15) was investigated further using O-D photochemical model simulations of the marine surface air sampled during GCE/CASE/WATOX. The model inc1udes a standard scheme for computing UV radiation intensities [Logan et a1., 1981] and a detailed $\mathrm{HO}_{-}-\mathrm{NO}_{x}$-hydrocarbon chemical mechanism (Lurmann et a1. [1986], with modifications by Jacob and Wofsy [1990]). The mechanism was extended to include gas-phase C1 reactions [Atkinson and Aschmann, 1985; DeMore et a1., 1987; Wa11ington et a1.. 1988; Nicovich et a1., 1990; Nielsen et a1., 1990], and surface reactions of sea-salt aerosol with $\mathrm{O}_{3}$ (reaction (15)) and $\mathrm{ClNO}_{3}$ (reaction $(4)$ ). Rates for the surface reactions are expressed as the gas-to-aerosol fluxes of $\mathrm{O}_{3}$ and $\mathrm{ClNO}_{3}$, weighted by a 'sticking coefficient" representing the reactivity of the gas at the surface. The same seasalt aerosol size distribution is assumed as in section 4.1. An excess surface concentration of $\mathrm{Cl}^{-}$is assumed, i.e., the reaction rates are not 1 imited by $\mathrm{Cl}^{-}$ availability. A sticking coefficient of unity for $\mathrm{ClNO}_{3}$ is chosen as an upper 1 imit [Finlayson-Pitts et a1., 1989]. The sticking coefficjent for $\mathrm{O}_{3}$ is chosen in the range of $10^{-4}$ to $10^{-3}$ to generate $\mathrm{Cl}^{-}$ loss rates of the order of $1 \mathrm{ppbv} \mathrm{h}^{-1}$ ( see section 3.7 ).

Our first set of simulations considers a closed air parcel in photochemical steady state at noon. Concentrations of " $\mathrm{NO}_{x^{\prime}} \mathrm{O}_{3}, \mathrm{CO}$, and HC1 a re fixed at 0.3 , $16,{ }^{x} 100$, and $0.5 \mathrm{ppbv}$, respectively, on the bas is of the GCE/CASE/WATOX data. Concentrations of hydrocarbons, $\mathrm{CO}$, and DMS are fixed on the basis of previous observations in the NAO [Rudolph and Ehha1t, 1981; Marenco and Said, 1989; Andreae et a1., 1985]. Concentrations of radicals and secondary hydrocarbons, are assumed to be at chemical steady state and define in particular the partitioning of
* NO between NO and peroxyacyl nitrates. Steady-state conditions are also assumed for $\mathrm{HOCl}$ and $\mathrm{Cl}_{2}$.

Selected results from five simulations are compared in Table 3 . Simulation $A$ includes no $\mathrm{Cl}$ - chemistry and is used as reference. Simnlations B-E test the effect of various C1 chemistry schemes. The effect of $\mathrm{Cl}^{\circ}$ production from the HC1 + OH reaction (simulation B) is 1 imited to a relatively small onhancement in the oxidation rate of alkanes, as was discussed previously by Singh and Kasting [1988]. Perturbations to the $\mathrm{HO}_{-}-\mathrm{NO}_{3}-\mathrm{O}_{3}$ budgets are negligiblo because the photochemistry is $\mathrm{NO}_{x}-1$ imited. Inclusion of the $\mathrm{ClNO}_{3}$ surface reaction as a source of $\mathrm{Cl}_{2}$ (simulation C) has no significant effect because the production of $\mathrm{C} 10$ (precursor of $\mathrm{ClNO}_{3}$ ) is inhibited by reactions of $\mathrm{C1}$ - with hydrocarbons. This result is again in harmony with the mode 1 calculations of Singh and Kasting [1988], and with our previous assessment that the 1ow concentrations of coarse particulate $\mathrm{NO}_{3}{ }^{-}$measured during the experiment suggest that reactions involving $\mathrm{C}_{1} \mathrm{NO}_{3}$ were of only minor importance (see section 3.4).

Inclusion of the $\mathrm{O}_{3}$ reaction at $\mathrm{NaCl}$ surfaces (simulations $D$ and $E$ ) introduces major perturbations to photochemistry. Oxidation by $\mathrm{C} 1$ - becomes a major atmospheric sink for DMS and hydrocarbons. The rapid production of $\mathrm{Cl}$. promotes $\mathrm{C}_{1} \mathrm{NO}_{3}$. formation, enhancing the oxidation of ${ }^{*} \mathrm{NO}$ to $\mathrm{NO}_{3}{ }^{-}$as well as the removal of $\mathrm{O}_{3}$. The oxidation of alkenes by $\mathrm{C} 1$. generates peroxyacyl radicals, shifting the composition of the NO pool towards peroxyacyl nitrates relative to simulations A-C. As a result of these two factors, we find in simulation $E$ that photochemical production of $\mathrm{O}_{3}$ is large1y suppressed.

The short 1 ifetime of "NO ${ }_{x}$ in simulation $E(1,4$ hours) seems inconsistent with the high *NO concentrations measured by Hastie et a1. [1990] during GCE/CASE/ WATOX. This lifetime is computed for surface air conditions, however, and longer lifetimes would be expected at higher atitudes where sea-salt aerosol concentrations are lower [e.g., Blanchard [1983], Table 2). It is possib1e that NO from aloft was mixed down and contributed to the higher concentrations measured from the ship. Photolysis of aerosol $\mathrm{NO}_{3}^{-}$could also possibly regenerate NO [Petriconi and Papee, 1972; Zafiriou and True, 1979]. Alternative1y, the higher sticking coefficient for $\mathrm{O}_{3}$ in 
TABLE 3. Mode1 Resu1ts for a Surface Air Parcel in Photochemical Equilibrium at Noon

\begin{tabular}{|c|c|c|c|c|c|}
\hline & \multicolumn{5}{|c|}{ Simulations } \\
\hline & A & B & $\mathbf{C}$ & $\mathbf{D}$ & $\mathbf{E}$ \\
\hline \multicolumn{6}{|c|}{ Concentrations } \\
\hline$\cdot 0 \mathrm{H}, \times 10^{6} \mathrm{~cm}^{-3}$ & 7.5 & 7.5 & 7.5 & 7.1 & 4.6 \\
\hline $\mathrm{c} 1 \cdot, \times 10^{3} \mathrm{~cm}^{-3}$ & & 6.1 & 6.4 & 130 & 1100 \\
\hline $\mathrm{NO}_{\mathrm{x}},{ }^{\mathrm{a}} \mathrm{ppbv}$ & 0.25 & 0.25 & 0.25 & 0.23 & 0.14 \\
\hline \multicolumn{6}{|c|}{ Rates of Chemical Production (P) and Loss (L), ppbv $\mathrm{h}^{-1}$} \\
\hline$(\mathrm{P}-\mathrm{L})$ of $\mathrm{O}_{3}$ & 1.4 & 1.4 & 1.4 & 1.4 & 0.14 \\
\hline$(P-L)$ of ${ }^{*} \mathrm{NO}_{\mathrm{x}}$ & -0.051 & -0.051 & -0.053 & -0.064 & -0.22 \\
\hline $\mathrm{L}$ of $\mathrm{Cl}^{-}$ & 0 & 0 & $<0.001$ & 0.22 & 2.2 \\
\hline $\mathrm{L}$ of $\mathrm{C}_{1} \mathrm{NO}_{3} \mathrm{~b}$ & 0 & 0 & $<0.001$ & 0.013 & 0.17 \\
\hline \multicolumn{6}{|c|}{ Rates of Oxidation by $\mathrm{Cl}^{\circ}$. Relatiye to those by ${ }^{\circ}$ OH } \\
\hline DMS & 0 & 0.0009 & 0.009 & 0.19 & 2.7 \\
\hline $\mathrm{C}_{3} \mathrm{H}_{8}$ & 0 & 0.009 & 0.10 & 1.97 & 27 \\
\hline $\mathrm{C}_{3} \mathrm{H}_{6}$ & 0 & 0.008 & 0.008 & 0.17 & 2.4 \\
\hline
\end{tabular}

Simulations are as follows: A, no Cl chemistry; B, gas-phase C1 chemistry only; C, simulation $B$ with surface reaction $\mathrm{ClNO}_{3}+\mathrm{Cl}^{-}$added; $\mathrm{D}$, simnlation $\mathrm{C}$ with surface reaction $\mathrm{O}_{3}+\mathrm{C}^{-}$added (sticking coefficient of $10^{-4}$ ); $\mathrm{E}$, simulation $\mathrm{C}$ with surface reaction $\mathrm{O}_{3}+\mathrm{C1}^{-}$added (sticking coefficient of $10^{-3}$ ).

${ }^{a}$ Computed from the photochemical partitioning of 0.3 ppbv "NO between NO and peroxyacyl nitrates (see text).

${ }^{b}$ Including only the uptake at sea-salt aerosol surfaces. Other CiNO 3 loss mechanisms are thermal decomposition, photolysis, and reaction $\mathbf{w t h}^{\circ} \mathrm{OH}$.

simulation $E$ (Table 3 ) may have resulted in overestimates for rates of $\mathrm{Cl}_{2}$ production.

The diel cycle of $\mathrm{Cl}^{\circ}$ chemistry was examined by integrating the $0-D$ simulation over 48 hours, starting at midnight. Concentrations of "NO $x$, DMS, CO, and primary hydrocarbons are fixed at the same levels as before, while concentrations of other species (including HC1) are allowed to evolve as independent variables. Removal of HCl is regulated by the gas-toaerosol flux, with a sticking coefficient of 0.15 [Watson et al., 1990]. The sticking coefficient for $0_{3}$ is taken as $10^{-3}$ in the daytime. At night we either use the same value (simulation $A^{\prime}$ ) or reduce it to $10^{-5}$ (simulation $B^{\prime}$ ). The lower sticking coefficient at night is intended to simulate the 1 ight dependence of $\mathrm{Cl}_{2}$ production observed by Behnke and Zetzsch [1989].

Results for $\mathrm{BC} 1, \mathrm{Cl}_{2}$, and $\mathrm{C1} 1^{-}$concentrations are shown in Figure 6. The sum of $\mathrm{HC} 1$ and $\mathrm{Cl}_{2}$ concentrations in the day- time is $0.3-0.5 \mathrm{ppbv}$, consistent with the observed aerosol $\mathrm{Cl}^{-}$losses. The higher $\mathrm{C}^{-}$deficits at night (Figure 5) can be explained by nighttime accumulation of $\mathrm{Cl}_{2}$. Simulation $\mathrm{A}^{\prime}$ indicates a $\mathrm{Cl}_{2}$ accumulation of 7 ppbv at night, which in reality may be 1 imited by the availability of $\mathrm{Cl}^{-}$aerosol. The accumulation of $\mathrm{Cl}_{2}$ to high levels at night, as in simulation $A^{\prime}$, would produce a surge in $\mathrm{C}^{\circ}$ ' concentrations at sunrise (Figure 6), which wonld in torn deplete DMS and biogenic hydrocarbons. However, observed DMS concentrations in surface air [Andreae t a1., 1985] show no evidence of rapid depletion at sunrise. It appears that nightime accumulation of $\mathrm{Cl}_{2}$ must be limited in some way, by either inefficient production or chemical removal. As shown in simulation $B^{\prime}$, a decrease in the rate of nighttime $\mathrm{Cl}_{2}$ production can effectively suppress the sunrise surge in $C_{1}$. concentrations. Reaction of $\mathrm{Cl}_{2}$ with DMS [Nielsen et a1., 1990] could reduce nighttime $\mathrm{Cl}_{2}$ levels further. 

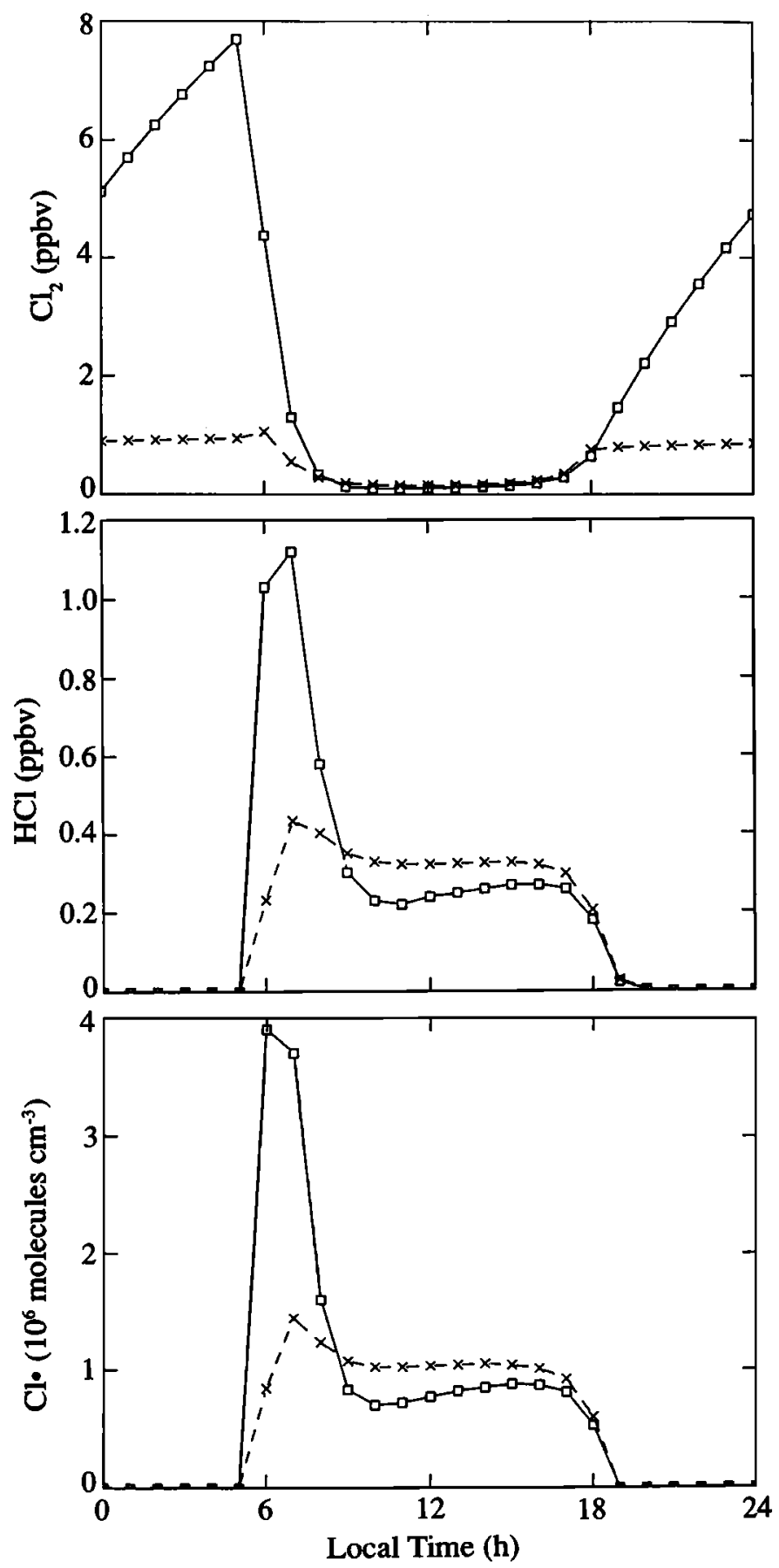

Fig. 6. Simulated concentrations of $\mathrm{Cl}_{2}$, $\mathrm{HC} 1$, and $\mathrm{C1}$. in marine surface air, as a function of time of day. Model conditions a re based on the GCE/CASE/ WATOX data. A sticking coefficient of $10^{-3}$ is assumed for the $0_{3}$ reaction at $\mathrm{NaC1}$ aerosol surfaces in the daytime. The sticking coefficient at $n$ ight is assumed identigal to that during the day (simulation $A^{\prime}$; squares), or is reduced to $10^{-5}$ (simulation B'; crosses). 


\section{SUMMARY}

Major hypothesized reactant and product species associated with the heterogeneous generation of volatile inorganic Cl from reactions involving sea-salt aerosol in the marine troposphere were measured as a function of phase, particle size, and altitude during the GCE/CASE/WATOX experiment of summer 1988. Air was sampled from the NOAA King Air research aircraft over the western NAO with a dichotomous system which incorporated bu1k and fine ( $50 \%$ ae rodynamic-cut radius of $0.4 \mu \mathrm{m}$ ) filter packs. Air was al so sampled throughout the NAO with two bulk filter pack samplers, a hivo1 aerosol sampler, and two cascade impactors (six and seven stages) mounted on a 10-m bow tower on the NOAA ship Mt. Mitche11. Data from paired collections with bulk and size-segregated samplers indicate that particle-toparticle and gas-to-particle reactions on bulk aerosol prefilters may cause large (factor of 2) positive artifacts in the measurement of $\mathrm{HCl}$ vapor and aerosol $\mathrm{Cl}^{-}$ deficits.

Concentrations of HC1 near the surface were typical1y less than 1.0 ppbv and decreased with altitude and with distance from the U.S. east coast. Concentrations of C1 volatilized from aerosols were generally equivalent to the corresponding concentrations of $\mathrm{HC} 1$. $\mathrm{C1}^{-}$deficits for the particnlate phase ranged from less than detection 1 imits to 125 nmol $\mathrm{m}^{-3}$ STP with the highest absolnte and percentage losses of C1 typically associated with elevated concentrations of anthropogenic combustion products. Concentrations of product $\mathrm{SO}_{4}{ }^{2-}$ and $\mathrm{NO}_{3}{ }^{-}$in coarse fractions of aerosol samples indicate that the combined effect of acid-base desorption and reactions involving $\mathrm{N}$ gases $\left(\mathrm{NO}_{2}, \mathrm{ClNO}_{3}\right.$, $\mathrm{N}_{2} \mathrm{O}_{5}$, and $\mathrm{HNO}_{3}$ ) and sea-salt aerosol could account for maxima of between 4 and $57 \%$ of measured $\mathrm{Cl}^{-}$deficits. This suggests that other processes may be occurring that lead to C1 loss from sea-salt aerosol.

We hypothesize a photochemical mechanism for the c1 loss which involves the reaction of $\mathrm{O}_{3}$ at $\mathrm{NaCl}$ surfaces to generate $\mathrm{Cl}_{2}$. Rapid photolysis of $\mathrm{Cl}_{2}$ during the day produces $\mathrm{C1}^{\circ}$, which initiates photochemical reactions in an analogous manner to $\mathrm{OH}$, yielding HCl. $\mathrm{HC} 1$ is then scavenged efficiently by the aerosol, closing the cl cycle. Alkalinity produced by this mechanism would explain anion deficits measured in coarse-fraction aerosol. In addition, the accumulation of $\mathrm{Cl}_{2}$ during the night that is expected from such a mechanism would explain the significant diel periodicity in the magnitude of $\mathrm{C1}^{-}$deficits measured in aerosols during the experiment. Steady state between $\mathrm{Cl}_{2}$ volatilization from the aerosol and between scavenging of HC1 by the aerosol implies a $\mathrm{Cl}_{2}$ source of the order of 1 ppbv $h^{-1}$ during the day. Uptake of $O_{3}$ by sea-salt aerosol may represent an important global sink for tropospheric $\mathrm{O}_{3}$, contributing to the $10 \mathrm{w}$ concentrations observed in many oceanic regions. Simulations with a $0-D$ photochemical model suggest that oxidation by $\mathrm{Cl}$ may be a major atmospheric sink for DMS and hydrocarbons. The geochemical cycling of $C 1$ could thrs have a significant influence on the oxidative state of the marine troposphere.

APPENDIX : ASSESSMENT OF ARTIFACTS IN HCL AND NSS $\mathrm{CL}^{-}$DATA

Potential sources of bias in measurements of $\mathrm{HCl}$ and $\mathrm{nss} \mathrm{C1}^{-}$include nonspecificity of the sampling media, volatilization resulting from pressure drops, losses of $\mathrm{HCl}$ to inlet or cyclone walls, chemical reactions between different size classes of particles collected in bulk, and chemical reactions between collected particles and gases in the airstream. Alkal ine-reactive C1 vapor was sampled quantitatively by the impregnated filters and was measured precisely by our analytical technique [Bardwe11 et al.. 1990]. Previous testing has shown that carbonate impregnated filters selectively exclude organic C1 gases [e.g., Rahn et a1., 1976: Berg and Winchester, 1977]. Since HC1 is thought to be the principal component of $\mathrm{Cl}^{\mathrm{i}}$ during the daytime (see, for example, sections 1 and 4.2), large bias in our reported HC1 data is not expected as a result of the specificity of the sampling media. HC1 was measured only during the day in conjunction with a ircraft sampling. In addition, the low pressure drop across the UVA/AQG filter packs [Bardwe11 et a1.., 1990] should minimize artifacts resulting from volatilization of particulate $\mathrm{Cl}^{-}$. Indepondent information is not available to assess criticaly the potential loss of $\mathrm{HCl}$ to inlet and cyclone walls.

The mixture of coarse (predominantly sea salt) and fine (predominantly sulfur) aerosol on a single filter may generate artifact $\mathrm{HCl}$ and $\mathrm{C1}^{-}$deficits $\mathrm{via}$ reactions (1) and (2) [e.g., Berg and Winchester, 1977; Perdue and Beck, 1988]. Two 
sets of paired data were inspected for evidence of such artifacts. Excluding two samples collected on July 17 in heavily polluted coastal air, data for the UVA/AQG dichotomous sampler on the aircraft show a consistent pattern (12 of 12 observations) of unneutralized acidity (estimated as [nss $\left.\mathrm{SO}_{4}^{2-}\right]+\left[\mathrm{NO}_{3}^{-}\right]-\left[\mathrm{NH}_{4}^{+}\right]$on an equivalent basis) in the fine aerosol fraction of BL air. Relative to HC1 measured with fine filter packs, concentrations of HC1 from concurrent bulk filter packs were systematical1y higher (11 of 12 cases) by an average factor of 2.3. These observations are consistent with the hypothesis that acidic fine aerosol reacted with sea-salt aerosol on bulk prefilters to produce artifact $\mathrm{HC} 1$ and $\mathrm{Cl}^{-}$deficits.

Six data pairs for the AOML hivol and URI cascade impactor, which were generated during overlapping but not entirely concurrent sampling periods, were also inspected for evidence of such artifacts. $\mathrm{C1}^{-}$deficits measured with the AOML hivol were higher relative to those for the impactors in four of six cases by an average factor for all data pairs of 2.1 . Unnentralized acidity estimated for fine fraction aerosol (stages 5 and 6 of the impactor) could account for approximately $50 \%$ of the observed average difference. This suggests that particle-to-particle reactions, though potentially important, did not generate all of the artifact $\mathrm{C1}^{-}$ deficit inferred from differences between the paired observations.

The presence of alkaline material such as sea-salt aerosol on bulk filters could scavenge $\mathrm{HNO}_{3}$ [e.g., Savoie et a1.. 1989] and $\mathrm{SO}_{2}[\mathrm{e} . \mathrm{g}$., Coutant, 1977] from the aistream, resulting in the production of artifact $\mathrm{BC}_{1}$ and $\mathrm{Cl}_{1}$ deficits $v$ ia reactions (1) and (2). Paired data from the UVA/AQG dichotomons sampler on the aircraft reveal significantly higher $(7 \%$ on average) concentrations of $\mathrm{SO}_{2}$ downstream of the fine aerosol prefilter relative to the bulk aerosol prefilter [Bardwe11 et a1.. 1990], suggesting that $\mathrm{SO}_{2}$ may have been scavenged by sea-salt on the bulk prefilter. If the scavenged $\mathrm{SO}_{2}$ reacted to produce HCl, the average positive bias in $\mathrm{BC} 1$ would be 1 ess than 5\%. Because $\mathrm{HNO}_{3}$ was apparently lost on the wall of the cyclone [Bardwe11 et a1., 1990], paired measurements of $\mathrm{HNO}_{3}$ could not be assessed similarly for evidence of artifacts.

Data from the AOML hivol and the URI cascade impactor were also inspected for evidence of gas-to-particle reactions on bulk aefosol filters. Concentrations of nss $\mathrm{SO}_{4}{ }^{2-}$ and $\mathrm{NO}_{3}{ }^{-}$were summed for all stages of each impactor sample and compared with the corresponding sum for each hivol. Sums for hivol samples were greater that those for cascades in five of six cases by an average factor for all data of 1.3. Higher $\mathrm{Cl}^{-}$deficits were observed in four of the five cases where hivol sums exceeded those for cascades. These relationships suggest that alkaline-reactive $S$ and $N$ gases may have been scavenged by sea-salt aerosol on the bulk filter, leading to artifact $\mathrm{Cl}^{-}$deficits.

The above assessment indicates that particle-to-particle and gas-to-particle reactions on bulk filters may be important sources of bias in measurements of HC1 and $\mathrm{Cl}^{-}$deficits. A more detailed evaluation is available upon request from the authors.

Acknowledgments. Te thank Captain D. E. Nortrup and the crew of the NOAA ship Mt. Mitche11 for their enthusiastic support of the Global Change Expedition; R. Duce for loan of the bow tower on the ship; L. Gunter for operating the sampler on the aircraft and providing the flow data; D. Wellman for assisting in developing the aircraft sampler; $T$. Gates and R. Morris for piloting the NOAA King Air; H. Cruden for fabricating the UVA/AQG sampler used on the ship; C. Bardwell, C. Brown, J. Hurt, J. Maben, and D. Smith for assisting in developing and testing the measurement systems, collecting the samples, and generating the resulting data: D. Hastie for providing data for No and $\mathrm{NO}_{\mathrm{y}} ; \mathrm{R}$. Artz, J. Harris, and J. Merrill for calculating air-mass trajectories and interpreting meteorology; B. Morris for expert clerical assistance; and the Bermuda Biological station for Research, Inc., for supporting aircraft operations. Comments and suggestions by R. Atkinson, T. Graede1, G. Harvey, J. Rudolph, P. Wine, O. Zafiriou, and the anonymous reviewers were very helpful. Financial support was provided by the NOAA Air Resources Laboratory, NOAA AOML, NOAA Radiatively Important Trace Species (RITS) Program, and National Science Foundation (NSF-ATM88-58974). This is a contribution to the Western Atlantic Ocean Experiment (TATOX).

\section{REFERENCES}

A1tshu1ler, A. P., Natural sources of gaseous pol1utants in the atmosphere, Te11us, 10, 479-492, 1958. 
Andreae, M. 0., R. J. Ferek, F. Bermond, K. P. Byrd, R. Y. Engstrom, S. Hardin, P. D. Houmere, F. LeMarrec, H. Raemdonck, and R. B. Chatfie1d, Dimethyl sulfide in the marine atmosphere, $J$. Geophys. Res.s. 90, 12,891-12,900, 1985 .

Atkinson, R., and S. M. Aschmann, Kinetics of the gas phase reaction of $C 1$ atoms with a series of organics at $296 \pm 2 \mathrm{~K}$ and atmospheric pressure, Int. J. Chem. Kin., 17, 33-41, 1985.

Bardwe11, C. A., J. R. Maben, J. A. Hurt, W. C. Keene, J. N. Galloway, J. F. Boatman, and $D$. Wellman, A technique utilizing high-flow, dichotomous filter packs for measuring major atmospheric chemical constituents, Global Biogeochem. Cycles. in press, 1990.

Behnke, W., and C. Zetzsch, Smog chamber investigations of the influence of $\mathrm{NaCl}$ aerosol on the concentrations of $\mathrm{O}_{3}$ in a photosmog system, in Ozone in the Atmosphere, Proceedings of the Quadrennial Ozone Symposium 1988 and Tropospheric Ozone Workshop, edited by B. D. Bojkov and P. Fabian, pp. 519-523, A. Deepak, Hampton, Va., 1989.

Berg, W. W., and J. W. Winchester, Organic and inorganic gaseous chlorine in relation to the particle size distribution of chloride in the marine aerosol, $J$. Geophys. Res.. 82, 5945-5953, 1977.

B1anchard, D. C., The production, distribution, and bacterial enrichment of the sea-salt aerosol, in Air-Sea Exchange of Gases and Particles, edited by P. S. Liss and W. G. N. S1inn, pp. 407-454, D. Reide1, Hingham, Mass., 1983.

Boatman, J. F., W. C. Keene, M. Luria, J. D. Ray, C. A. Bardwe11, K. Gorze1 ska, M. Fenne11, D. R. Hastie, A. A. P. Pszenny, and D. Whelpdale, An intercomparison of the chemical and meteorological data generated from aircraft and shipboard sampling during GCE/CASE/ WATOX, NOAA Tech, Memo. ERL ARL-186, Air Resonr. Lab., Silver Spring, Md., in press, 1990.

Brimblecombe, P., and S. L. Clegg, The solubility and behaviour of acid gases in the marine aeroso1, J. Atmos. Chem., 7. 1-18, 1988

Chameides, W. L., and D. D. Davis, The free radical chemistry of cloud droplets and its impact upon the composition of rain, J. Geophys. Res.. 87, 4863-4877, 1982.

Cicerone, R. J., Halogens in the atmosphere, Rev. Geophys.. 19, 123-139, 1981.

Coutant, R. W., Effect of environmenta 1 variables on collection of atmospheric sulfate, Environ. Sci. Techno1, 11, 873$878,1977$.

DeMore, W. B., M. J. Molina, S. P. Sander, D. M. Golden, R. F. Hampson, M. J. Knrylo, C. J. Howard, and A. R. Ravishankara, Chemical kinetics and photochemical data for use in stratospheric mode1ing, JPL Pub1. 87-41, Jet Propu1. Lab., Pasadena, Ca1 if ., 1987.

Duce, R. A., On the source of gaseous chlorine in the marine atmosphere, $\mathrm{J}$. Geophys. Res.. 74, 4597-4599, 1969.

Erickson, D. J., and R. A. Duce, On the global flux of atmospheric sea salt, J. Goophys, Res., 93, 14,079-14,088, 1988 .

Eriksson, E., The yearly circulation of chlorine and sulfur in natare: Meteorologica1, geochemical and pedological imp1ications, 1, Te11 us, 11, 375-403, 1959.

Fin1ayson-Pitts, B. J., Reaction of $\mathrm{NO}_{2}$ with $\mathrm{NaCl}$ and atmospheric implications of NOC1 formation, Nature, 306, 676-677, 1983.

Finlayson-Pitts, B. J., M. J. Eze11, and J. N. Pitts, Jr., Formation of chemically active chlorine compounds by reactions of atmospheric NaCl particles with gaseous $\mathrm{N}_{2} \mathrm{O}_{5}$ and $\mathrm{ClONO}_{2}$, Nature, 337 , 241- 244, 1989 .

Fishman, J., C. E. Watson, J. C. Larsen, and $J$. A. Logan, Distribution of tropospheric ozone determined from satellite data, J. Geophys. Res.. 95, 3599-3617, 1990.

Fogg, T. R., Absorption of gases by cellulose fiber cascade impactor surfaces, Atmos. Enyiron., 20, 1633-1634, 1986.

Friend, J. P., Natural chlorine and f1uo$r$ ine in the atmosphere, water and precipitation, in Scientific Assessment of Stratospheric Ozone: 1989, vol. II, Appendix: AFEAS Rep.. 1989, Rep, 20, Global Ozone Res. and Monit. Proj.., World Meteorol. Organ., Geneva, 1989.

Fuchs, N. A., and A. G. Sutagin, Highdispersed aerosols, in International Reviews of Aeroso1 Physics and Chemis try, vo1. 2, edited by G. M. Hidy and J. R. Brock, pp. 1-60, Pergamon, New York, 1971.

Hansen, A. D. A., R. S. Artz, A. A. P. Pszenny, and R. E. Larson. Aerosol black carbon and radon as tracers for air mass origin over the North Atlantic Ocean, Global Biogeochem. Cycles, in press, 1990.

Hastie, D. R., S. Malle, D. L. Toom, D. M. Whelpdale, W. C. Keene, J. N. Galloway, J. R. Maben, and A. A. P. Pszenny, Inorganic nitrogen over the western North 
Atlantic Ocean, Global Biogeochem. Cyc1es, in press, 1990.

Heikes, B. G., Aqueons $\mathrm{H}_{2} \mathrm{O}_{2}$ production from $\mathrm{O}_{3}$ in g1ass impingers, Atmos. Environ., 18, 1433-1445, 1984.

Jacob, D. J., Chemistry of OH in remote clouds and its role in the production of formic acid and peroxymonosulfate, $\mathrm{J}$. Geophys. Res.. 91, 9807-9826, 1986.

Jacob, D. J., and S. C. Wofsy, Budgets of reactive nitrogen, hydrocarbons, and ozone over the Amazon forest during the wet season, J. Geophys. Res..2 95, $16,737-16754,1990$.

Jayson, C. G., B. J. Parsons, and A. J. Swallow, Some simple and highly reactive chloride derivates in aqueous solution, J. Chem. Soc. Faraday Trans. 1, 69, 1597-1607, 1973.

Kitto, M. E., and D. L. Anderson, Comments on 'The use of Whatman 41 filters for particle collection, ' Atmos. Environ.. 22, 2629-2630, 1988 .

Kritz, M. A., and J. Rancher, Circulation of $\mathrm{Na}, \mathrm{C1}$, and $\mathrm{Br}$ in the tropical marine a tmosphere, J. Geophys, Res.. 85, 16331639,1980 .

Legrand, M., and R. J. Delmas, Formation of $\mathrm{HCl}$ in the Antarctic atmosphere, J. Geophys, Res.2 93, 7153-7168, 1988.

Levy, H., II, and W. J. Moxim, Simulated global distribution and deposition of reactive nitrogen emitted by fossil fuel combustion, Tellus, Ser. B, 41, 256271, 1989.

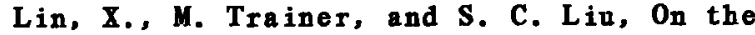
non-1inearity of tropospheric ozone production, J, Geophys. Res.. 93. 15,879-15,888, 1988 .

Lin, S. C., M. McFarland, D. K1ey, 0. Zafiriou, and B. Buebert, Tropospheric $\mathrm{NO}_{x}$ and $\mathrm{O}_{3}$ budgets in the equatorial Pacific, J. Geophys, Res.. 88, 1360$1368,1983$.

Lodge, J. P., Editoxial: Use of Whatman 41 filter papers in particle sampling, Atmos. Environ., 20, 1657, 1986.

Logan, J. A., M. J. Prather, S. C. Wofsy, and $M$. B. McElroy, Tropospheric chemistry: A global perspective, J. Geophys. Res., 86, 7210-7254, 1981 .

Lovett, R. F., Quantitative measurement of a irborne sea-salt in the North Atlantic. Te11us, 30, 358-364, 1978.

Lowentha1, D. H., and K. A. Rahn, Further comments on 'The use of Whatman 41 filter papers for high volume aerosol samp1ing," Atmos, Environ.2. 21, 2732-2734, 1987 .

Lurmann, F. W., A. C. Lloyd, and R. Atkinson, A chemical mechanism for ase in long-range transport/acid deposition model ing. J. Geophys. Res.. 91, 10,905$10,936,1986$.

Marenco, A., and F. Said, Meridional and vertical ozone distribution in the background troposphere $\left(70^{\circ} \mathrm{N}-60^{\circ} \mathrm{s} ; 0-12 \mathrm{~km}\right.$ altitude) from scientific arcraft measurements during the STRATOZ III experiment (June 1984), Atmos, Environ.. 23, 201-214, 1989.

Martens, C. S., J. J. Wesolowski, R. C. Harriss, and $R$. Kaifer, Chlorine loss from Puerto Rican and San Francisco Bay area marine aeroso1s, J, Geophys. Res.. 78, 8778-8792, 1973.

McE1roy, W. J., A laser photolysis study of the reaction of $\mathrm{SO}_{4}$ with $\mathrm{Cl}^{-}$and the subsequent decay of $\mathrm{Cl}_{2}^{-}$in aqueous solntion, J. Phys. Chem.2 94, 2435-2441, 1990.

Newe11, R. E., and M. F. Wu, Simu1taneous measurements of carbon monoxide and ozone in the NASA Global Atmospheric Sampling Program (GASP), in Atmospheric Ozone, Proceedings, ozone Symposium, edited by C. S. Zeferos and A. Ghazi, pp. 548-552, D. Reide1, Hingham, Mass., 1985.

Nicovich, J. M., R. D. Kreutter, and P. H. Wine, Kinetics $g^{f}$ the reactions of C1 $\left({ }^{2} \mathrm{P}_{\mathrm{J}}\right)$ and $\mathrm{Br}\left({ }^{2} \mathrm{P}_{3 / 2}\right)$ with $\mathrm{O}_{3}$, Int. J. Chem. Kinet.2 22, 399-414, 1990 .

Niel sen, 0. J., H. W. Sidebottom, L. Ne1son, 0. Rattegan, J. J. Treacy, and D. J. O'Farre11, Rate constants for the reaction of $O H$ radicals and $C 1$ atoms with diethyl sulfide, di-n-propyl sulfide, and di-n-buty 1 sulfide, Int. $J$. Chem. Kinet., 22, 603-612, 1990.

Parungo, F. P., C. T. Nagamoto, J. Rosinski, and $P$. L. Haagenson, A study of marine aerosols over the Pacific Ocean, J. Atmos. Chem. 4, 199-226, 1986.

Perdue, E. M., and K. C. Beck, Chemical consequences of mixing atmospheric droplets of varied pH, J. Geophys. Res.. 93, 691-698, 1988 .

Petriconi, G. L., and H. M. Papee, On tho photolytic separation of halogens from sea water concentrates, Water Air Soil Pol1nt.. 1, 117-131, 1972.

Piotrowicz, S. R., D. A. Boran, and C. J. Fisher, Ozone in the boundary layer of the equitorial Pacific Ocean, J. Geophys. Res.e 91, 13,113-13,119, 1986.

Piotrowicz, S. R., C. J. Fisher, and R. S. Artz, Ozone and carbon monoxide over the North Atlantic during a boreal summer, G1oba1 Biogeochem. Cycles, in press, 1990.

Pszenny, A. A. P., A. J. Caste11e, J. N. 
Ga1loway, and R. A. Duce, A study of the sulfur cycle in the Antarctic marine boundary 1 ayer, J. Geophys. Res. 94 , 9818-9830, 1989.

Pszenny, A. A. P., J. N. Galloway, R. S. Artz, and J. F. Boatman, Overview of the $1988 \mathrm{GCE} / \mathrm{CASE} /$ WATOX studies of biogeochemical cycles in the North Atlantic region, Global Biogeochem. Cycles, in press, 1990a.

Pszenny, A. A. P., G. R. Harvey, C. J. Brown, R. F. Lang, W. C. Keene, J. N. Galloway, and $J$. T. Merril1, Measurements of dimethyl sufide oxidation products in the summertime North Atlantic marine boundary layer, G1obal Biogeochem. Cycles, in press, $1990 \mathrm{~b}$.

Rahn, K. A., R. D. Borys, and R. A. Duce, Tropospheric halogen gases: Inorganic and organic components, Science, 192, $549-550,1976$.

Rancher, J., and M. A. Kritz, Diurnal fluctuations of $B r$ and $I$ in the marine a tmosphere, J. Geophys. Res.e 85, 5581$5587,1980$.

Ray, J. D., C. C. Van Valin, M. Luria, and J. F. Boatman, Oxidants in the marine troposphere: $\mathrm{H}_{2} \mathrm{O}_{2}$ and $\mathrm{O}_{3}$ over the western Atlantic Ocean, Global Biogeochen. Cycles, in press, 1990.

Rudo1ph, J., and D. H. Ehha1t, Measurements of C2-C5 hydrocarbons over the North Atlantic, J. Geophys. Res.2 86, 11,959-11,964, 1981 .

Ryan, J. A., and N. R. Mukherjee, Estimate of tropospheric BCl cycle, report, 74 pp., McDonne11-Doug1as Co., Huntington Bend, Calif.. 1974.

Savoie, D. L., J. M. Prospero, and E. S. Saltzman, Non-sea-salt sulfate and nitrate in trade wind aerosols at Barbados: Evidence for long-range transport, J. Geophys. Res.. 94, 5069-5080, 1989 .

Schroeder, W. H., and P. Urone, Formation of nitrosy1 chloride from sea particles in a ir, Environ. Sci. Technol.. 8, 756$758,1974$.

Sievering, H., J. Boatman, J. Galloway, W. Keene, Y. Kim, M. Luria, and J. Ray, Heterogeneous sulfur conversion in seasalt aersol particles: The role of aerosol water content and size distribution, Atmos. Environ., in press, 1991.

Singh, H. B., and J. F. Kasting, Chlorinehydrocarbon photochemistry in the marine troposphere and lower stratosphere, $\mathrm{J}$. Atmos. Chem., 7, 261-285, 1988.

Stunder, B. J. B., R. S. Artz, G. D. Rolph, J. M. Harris, and J. T. Merrill, Summary of meteorological conditions over the North Atlantic Ocean during
WATOX 1988, Global Biogeochem. Cycles, in press, 1990.

Wa11, S. M., W. John, and J. L. Ondo, Heasurement of aerosol size distributions for nitrate and major ionic species, Atmos. Environ., 22, 1649-1656, 1988 .

Wa11 ington, T. J., L. M. Skewes, W. 0 . Sieg1, C. -H. Wa, and S. M. Japar, Gas phase reactions of $C 1$ atoms with a series of oxygenated species at $295 \mathrm{~K}$, Int. J. Chem. Kinet.. 20, 867-875, 1988 .

Watson, L. R., J. M. Van Doren, P. Davidovits, A. R. Worsnop, M. S. Zahniser, and C. E. Kolb, Optake of HC1 molecules by aqueous sulfuric acid droplets as a function of acid concentration, J. Geophys. Res., 95, 5631-5638, 1990.

Fatts, S. F., R. Yaaqub, and T. Davies, Comments on 'The use of Thatman $41 \mathrm{fil}$ ter papers for high volume aerosol samp1 ing." "Atmos. Enyiron.. 21, 2731-2732, 1987.

Willeke, K., Performance of the slotted impactor, Am. Ind. Hygiene Assoc. J., 36, 683-691, 1975 .

Winkler, P., Observations on acidity in continental and in marine atmospheric aerosols and in precipitation, J. Geophys. Res..2 85, 4481-4486, 1980.

Wink1er, P., Relations between aerosol acidity and ion balance, in Chemistry of Mu1tiphase Atmospheric Systems, NATO Adv. Study Inst. Ser.2 Ser. G.,., vo1.6, edited by W. Jaeschke, pp. 269-298, Springer-Verlag, New York, 1986.

Wofsy, S. C., and M. B. McElroy, HO ${ }_{x}, \mathrm{NO}_{x}$, and $\mathrm{ClO}_{x}$ : Their role in atmospheric photochemistry, Can, J. Chem., 52, 15821591,1974 .

Zafirion, 0. C., and M. B. True, Nitrate photolysis in seawater by sunlight, Mar. Chem.. 8, 33-42, 1979.

Zetzsch, C., G. Pfahler, and W. Behnke, Heterogeneons formation of chlorine atoms from $\mathrm{NaCl}$ in a photosmog system, J. Aerosol Sci.e 19, 1203-1206, 1988 .

J. F. Boatman, Aerosol Research Section, NOAA Air Resources Laboratory, Bou1der, Co 80303.

R. A. Duce, Graduate School of Oceanography, University of Rhode Island, Narragansett, RI 02882 .

J. N. Ga1loway and W. C. Keene, Department of Bnvironmental Sciences, University of Virginia, Charlottesville, VA 22903.

D. J. Jacob, Division of Applied Scien- 
ces, Harvard University, Cambridge, MA 02138 .

A. A. P. Pszenny, Ocean Chemistry Division, NOAA Atlantic Oceanographic and Meteorological Laboratory, 4301 Rickenbacker Canseway, Miami, FL 33149.

J. J. Schu1tz-Tokos, Institut fuer Meereskunde an der Universitaet Kiel, Duesternbrooker Weg 20, D-2300 Kie1, Germany.
H. Sievering, Center for Environmental Sciences, University of Colorado at Denver, Denver, Co 80204.

(Received February 15, 1990 ; revised October 31, 1990; accepted November 7, 1990.) 